\title{
Genotypic Variation in Apple Rootstock Low Temperature Tolerance During Spring and Fall
}

\author{
Renae E. Moran ${ }^{1}$ \\ School of Food and Agriculture, University of Maine, P.O. Box 179, Monmouth, ME 04259 \\ Bryan J. Peterson \\ School of Food and Agriculture, University of Maine, Deering Hall, Orono, ME 04469 \\ Gennaro Fazio \\ USDA-ARS Plant Genetic Resources Unit, Geneva, NY 14456 \\ John Cline \\ Department of Plant Agriculture, Ontario Agricultural College, University of Guelph, Horticultural \\ Experiment Station, Simcoe, ON N3Y 4N5, Canada
}

\begin{abstract}
Additional INDEX words. winterhardiness, freeze injury, xylem, cambium, phloem, Malus $\times$ domestica
Abstract. To identify genotypes of apple (Malus $\times$ domestica) rootstock with vulnerability to low temperature, we measured the low temperature tolerance of xylem, phloem and cambium in 2-year-old shoot pieces from cultivars Budagovsky 9 (B.9), M.7 EMLA (M.7), M.9 EMLA (M.9), Geneva ${ }^{\circledR} 41$ (G.41), Geneva 30 (G.30), Geneva 214 (G.214), Geneva 814 (G.814), and Geneva 935 (G.935), as well as six advanced selections in the Geneva (G.) series and three in the Vineland (V.) series. From Oct. 2013 to Apr. 2014, injury was measured as a 0-10 rating based on percentage of discolored cross-sectional xylem and phloem, and cambial length and circumference with brown discoloration, with 0 indicating no browning and 10 indicating browning in the entire tissue. From Oct. 2014 to Apr. 2015, injury was measured as xylem, phloem and cambium browning using a similar rating scale that accounted for both the percentage of browned tissues and the intensity of browning. Following exposure to -35 to $-40^{\circ} \mathrm{C}$, many genotypes, including 'M.7', 'M.9', 'G.935', G.4011, G.4292, G.5087, and V.5, had only partial xylem injury in the fall, whereas others, 'M.7', 'G.41', 'G.214', and G.4011, had more extensive xylem browning at $-30{ }^{\circ} \mathrm{C}$ and colder. 'G.30' had moderate to severe xylem browning at -15 to $-19^{\circ} \mathrm{C}$. In late October of both years, $\mathrm{G} .4013$ exhibited severe phloem browning at relatively high temperatures, but accrued additional hardiness by Nov. 2014, whereas genotypes 'B.9', 'M.9', 'G.30', and 'G.41' developed considerable phloem hardiness by late October with no additional increase in hardiness in November. Geneva and Vineland genotypes exhibited a low degree of susceptibility to injury at -35 to $-40^{\circ} \mathrm{C}$ in Jan. 2014 and Mar. 2015. Shoot hardiness in Apr. 2014 and 2015 was highly variable between the 2 years, with severe browning of xylem and cambium at $-40^{\circ} \mathrm{C}$ in every genotype sampled in Apr. 2014, but not in Apr. 2015. 'M.9' and G.3902 appeared to be the least vulnerable to injury in April, whereas 'G.30', 'G.41', 'G.814', G.4292, and G.5257 seem more likely to suffer injury in spring. 'G.30' had tender xylem in both fall and spring, G.4013 had the least hardy cambium and phloem in fall, and G.5257 the least hardy cambium in the spring. These genotypes are vulnerable to damaging temperatures during fall acclimation and spring deacclimation.
\end{abstract}

Trees suffer from lethal and sublethal injury when severely low temperatures occur before they develop cold hardiness, to a degree that exceeds their midwinter hardiness, or in the spring after they lose cold hardiness. In most regions of apple production, tree loss to low temperature injury occurs in fall when trees are acclimating or in spring during deacclimation. Apple trees acquire cold hardiness in late summer in response to shortened daylength and exposure to cold, and then to low temperatures in fall in the range of 1.3 to $-5.0{ }^{\circ} \mathrm{C}$ (Hong and Sucoff, 1982; Howell and Weiser, 1970a; Mathers and Stushnoff, 2005). When the occurrence of nonlethal freezing temperature is delayed, acclimation may also be delayed which creates conditions of plant vulnerability (Palonen and Buszard, 1997). Spring deacclimation occurs in response to high temperatures

Received for publication 31 May 2018. Accepted for publication 16 July 2018. Funded by the International Tree Fruit Association, New England Tree Fruit Growers Research Committee, and the National Institute of Food and Agriculture project NC140. Maine Agricultural and Forest Experiment Station Publication Number 3616.

${ }^{1}$ Corresponding author. E-mail: rmoran@maine.edu.
(Howell and Weiser, 1970b), and may occur transiently during brief warm spells followed by renewed cold.

Fruit tree rootstocks affect many aspects of scion performance, one of which is cold hardiness, particularly in the scion trunk (Layne, 1994; Layne et al., 1977; McArtney and Obermiller, 2011; Simons, 1970; Westwood and Bjornstad, 1981). When the trunk is damaged or girdled by low temperature injury, every part of the tree becomes stressed because of reduced functioning of vascular tissues. Tree or orchard replacement is necessary when tree mortality occurs, causing substantial losses for growers. Sublethal effects, including reduced shoot growth and small fruit size, also cause economic losses. In addition, repeated injury to xylem can favor invasion of damaged tissues by pathogens, such as wood-rotting fungi (Quamme et al., 1972; Tanino, 2012). The full economic costs may not be immediately evident, as sublethal damage may go unnoticed or may be confused with associated problems such as wood rot and cankers (Holubowicz et al., 1982). Injury to the trunk from the use of tender rootstocks also occurs in the nursery and can lead to tree shortages for growers and losses for the nursery industry. 


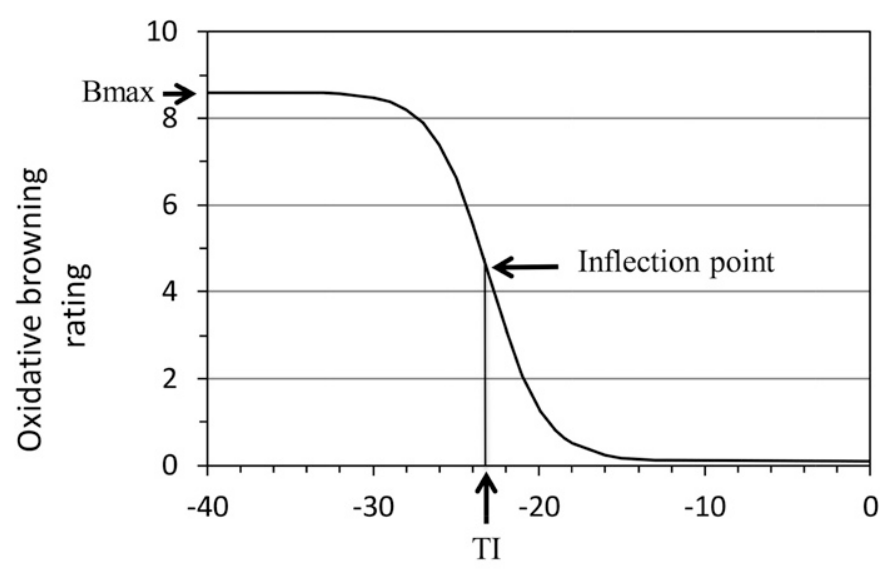

Temperature $\left({ }^{\circ} \mathrm{C}\right)$

Fig. 1. A temperature response function, $y=B \max /\left[1+\mathrm{e}^{\mathrm{b}(\mathrm{TI}-\mathrm{x})}\right]$, where $\mathrm{y}=$ the amount of tissue browning from none $(0)$ to severe $(10)$, and $\mathrm{x}=$ temperature. Bmax indicates the upper asymptote or the maximum amount of browning within the temperature range tested. The inflection point, $b$, is the point on the curve where the slope is greatest, and TI is the corresponding temperature.

Selection of adapted genotypes is the most effective method of preventing low temperature injury (Cummins and Aldwinkle, 1974). Following a December freeze in Washington state, trunk injury occurred in trees grafted to Malling rootstocks, but trees on 'M.7' showed better recovery than those on 'M.9' (Westwood and Bjornstad, 1981). Among the Malling cultivars, hardiness differences in stem tissue are minimal in November, but in May, 'M.9' had more injury than 'M.7', 'M.26', and 'MM.106' from natural freezing events (Wildung et al., 1973). Freeze-thaw cycles also damage tree trunks with the degree of damage governed by the rootstock genotype. After a severe freeze-thaw cycle in January in North Carolina, 'Golden Delicious' scions on 'M.9' and 'M.26' had greater trunk injury and subsequent reductions in tree growth than the same scion on 'G.935' and 'G.16' (McArtney and Obermiller, 2011). Naturally occurring freezes have been used to characterize rootstock cold hardiness, but such assessments are limited to genotypes in cultivation and can be confounded by other factors that influence tree performance. In controlled studies 'M.26' and 'Ottawa 3' have greater midwinter hardiness than 'M.7' and 'MM.106' (Embree, 1988), whereas 'B.9' has greater hardiness than 'G.30' and 'G.11' (Moran et al., 2011). In March, 'Ottawa 3' and 'Ottawa 4' have greater hardiness than Malling rootstocks (Holubowicz et al., 1982). Additional controlled studies are needed to determine the full seasonal low temperature tolerance in new cultivars. The Vineland rootstock breeding program, initiated in 1958, developed a series of several size-controlling rootstocks that were adapted to Canadian winters (Elfving et al., 1993). Geneva rootstocks were also selected for low temperature tolerance (Cummins and Aldwinkle, 1974). Cultivars and selections from these programs are likely to have greater midwinter low temperature tolerance based on genetic parents, but survival of freezing temperatures during acclimation and deacclimation is largely unknown.

Visual browning as a measure of injury has a stronger correlation with survival than electrical conductivity of leachates (Lapins, 1961). Blackheart, as a measure of xylem browning in the scion trunk, varies among rootstocks, but when less than $50 \%$ to $60 \%$ of the trunk cross-sectional area or branch is affected, there is no measurable effect on tree growth (Domoto et al., 2001; Moran et al., 2011; Steinmetz and Hilborn, 1938; Warmund et al., 1996). In apple trees, shoot mortality occurs with $80 \%$ xylem damage as measured in cross section, but not $60 \%$ (Pramsohler et al., 2012). Visual browning is useful for assessing injury in different tissues, but the level of browning that leads to mortality may differ between the xylem, cambium, and phloem.

Acclimation begins in distal parts of the tree and progresses toward the base, so the trunk is the last part of the aboveground tissues to acquire hardiness (Palonen and Buszard, 1997). For this reason, the trunk is typically less hardy than younger shoots on the same tree (Ketchie and Beeman, 1973; Quamme and Hampson, 2004), and displays more severe injury than other tree parts following injurious temperatures (Steinmetz and Hilborn, 1938). Crucially, it is because of this variation within each tree that 1-year-old shoots may not represent the hardiness of the rest of the tree (Quamme and Hampson, 2004).

In addition to the distal-basal variation in shoot hardiness, different tissues within the cross section of a shoot also differ in hardiness (Mathers, 2004; Quamme, 1976). In the fall, the phloem of apple and peach shoots is more tender than xylem and cambium, but develops greater hardiness than these tissues in midwinter (Nesmith and Dowler, 1976; Quamme et al., 1972). Cambial hardiness is not frequently measured, so injury to this tissue can go unnoticed. For these reasons, all three tissues should be considered in the measurement of shoot tissue hardiness.

The objective of this research was to measure low temperature tolerance in Geneva and Vineland apple rootstock genotypes during fall, winter and spring to identify genotypes with the least tolerance. Low temperature tolerance of xylem, cambium and phloem were evaluated through two experiments, the first conducted in the 2013-14 dormant season, and the second conducted in the 2014-15 dormant season.

\section{Materials and Methods}

Plant materials. One-year-old apple rootstocks as ungrafted liners were planted at Highmoor Farm in Monmouth, $\mathrm{ME}$, at a spacing of $15 \mathrm{~cm}$ and mulched with black plastic. The plastic mulch degraded after 3 years and was replaced by nursery groundcover (994GC; Lumite, Alto, GA). Geneva rootstocks 'G.214', 'G.814', 'G.935', G.3902, G.4011, G.4013, G.4292, G.5087, and G.5257 were planted in 2011, 'M.9 T337', 'M.7 EMLA', and Vineland selections V.5, V.6, and V.7 in 2012, and 'B.9', 'G.30', and 'G.41' in 2013, with 30 to 50 liners of each genotype planted. Trees were not fertilized during the study, and no supplemental irrigation was provided because tensiometers indicated that moisture was sufficient. Air temperature was measured by a thermistor and recorded hourly by a datalogger (model 107 thermistor, model 10X datalogger; Campbell Scientific, Logan, UT).

In Expt. 1, shoot hardiness was measured on 22 and 29 Oct. 2013, 14 Jan. 2014, and 10 Apr. 2014. 'M.7', 'M.9', 'G.30', 'G.41', 'G.214', 'G.814', 'G.935', G.3902, G.4011, G.4013, G.4292, G.5087, G.5257, V.5, V.6, and V.7 were measured each time except 'G.30', which was not measured in January to ensure that sufficient branches were available for the April measurement. Twelve branches of each genotype, sampled randomly from the available trees, were required to obtain six shoot pieces for each experimental freezing temperature. Most 
trees had developed more than one branch by 2013 , and some trees had more than one branch sampled over the course of the dormant season. Any difference in hardiness that occurred between 22 and 29 Oct. 2013 in Expt. 1 could not be detected statistically, but only three shoot-pieces for each date and temperature were measured. In Expt. 2, hardiness was measured on 30 Oct. and 13 Nov. 2014 to measure changes during acclimation over a 2-week period. 'B.9', 'M.9', 'G.30', 'G.41', 'G.214', 'G.814', 'G.935', G.3902, G.4011, G.4013, G.4292, G.5087, G.5257, V.5, V.6, and V.7 were measured both times. In Spring 2015, hardiness was measured again on 23 Mar. in 'M.9', 'G.214', 'G.814', 'G.935', G.4013, G.4292, G.5087, G.5257, V.5, and V.7 and on 8 April in 'B.9', 'M.9', 'G.30', 'G.814', 'G.935', G.3902, G.4011, G.4013, G.4292, G.5087, G.5257, V.5, V.6, and V.7. In Mar. 2015, 'B.9', 'G.30', 'G.41', G.3902, G.4011, and V.6 were not measured because of insufficient plant material. In Apr. 2015, 'G.41' and 'G.214' were omitted due to an oversight. In Expt. 1, 'M.7' and 'M.9' were used as controls because of their commercial importance and lack of winterhardiness, respectively. In Expt. 2, 'M.7' was replaced by 'B.9' as a cold hardy alternative to 'M.9'.

DETERMINATION OF COLD HARDINESS. Shoots were cut at the base of 2-year-old wood, but at a point above the snow cover level that was present in winter and spring. Whole shoots were transported at ambient temperatures to a laboratory at the University of Maine in Orono, where the 2-yearold sections were cut into 6- to $8-\mathrm{cm}$ pieces. Shoot pieces were wrapped with moist paper towels and placed in unsealed plastic bags. The collection of shoots, transport, and shoot processing took no more than $5 \mathrm{~h}$. The shoots in plastic bags were left at $20{ }^{\circ} \mathrm{C}$, as ambient-temperature controls, or placed in a temperaturecontrolled programmable freezer (SuperCold Freezer; Scientemp, Adrien, MI) and held at a temperature of $-7{ }^{\circ} \mathrm{C}$ for $16 \mathrm{~h}$. After this, the temperature was decreased to $-15^{\circ} \mathrm{C}$ and held for $1 \mathrm{hr}$, and then decreased in $5{ }^{\circ} \mathrm{C}$ intervals to a low of -35 or $-40^{\circ} \mathrm{C}$. Copper-constantan (Type T) thermocouples inserted between the bundled shoot pieces were
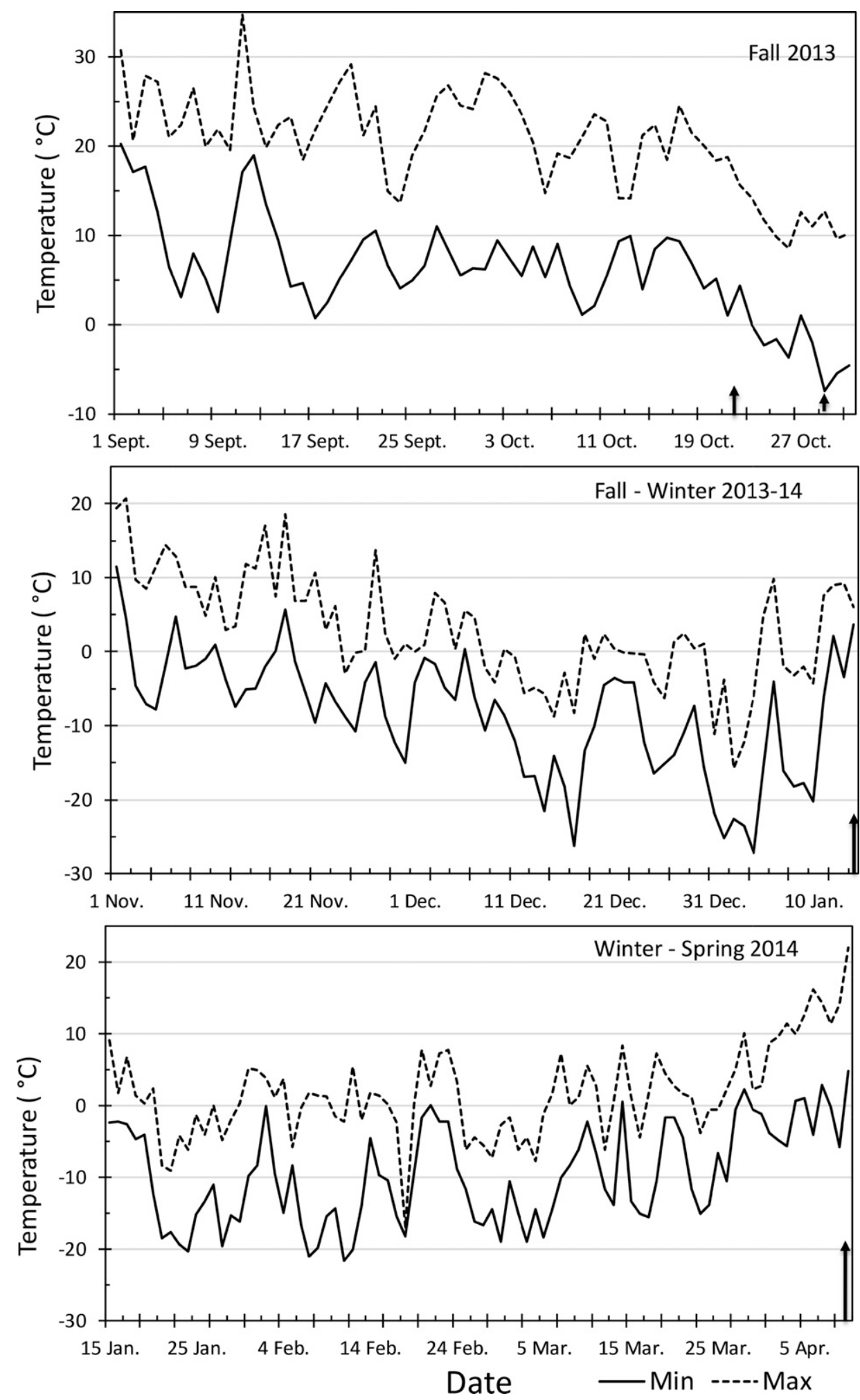

Fig. 2. Minimum and maximum air temperatures at the rootstock orchard in the weeks preceding low temperature tolerance measurements in Expt. 1. The arrows along the $\mathrm{x}$-axis indicate measurement dates. 
placed in cold storage at $1{ }^{\circ} \mathrm{C}$ until analysis of browning within 1 to 2 weeks.

Tissue browning was rated using a scale from 0 to 10 , where 0 indicated no browning and 10 indicated $100 \%$ of the xylem tissue area in cross section was discolored (Cline et al., 2012). Although the location of the xylem browning was not formally documented, we observed whether browning was more prevalent in the older, inner xylem or the younger, outer xylem next to the cambium. To assess browning of phloem and cambium, shoots were cut lengthwise to the depth of the outer xylem. Phloem browning was measured as the relative depth and length of phloem tissue that was discolored. Cambial browning was measured as the relative length and circumference of cambium that was discolored. Cambial browning was not measured until Jan. 2014 as experience was gained in distinguishing cambial tissues from surrounding xylem and phloem. In Expt. 2, discolored tissue was additionally rated according to its intensity of browning using a scale of 0 to 5 , where 0 indicated no browning and 5 indicated tissues were dark brown. In Expt. 2, both ratings were used to calculate an index of injury, which was the average of the two ratings according to the formula (area of discoloration + intensity of discoloration $x$ 2)/2. In Apr. 2014, discoloration of the cambium occurred in unfrozen controls of the Vineland selections that had been stored for 2 weeks, with greater browning in controls than in
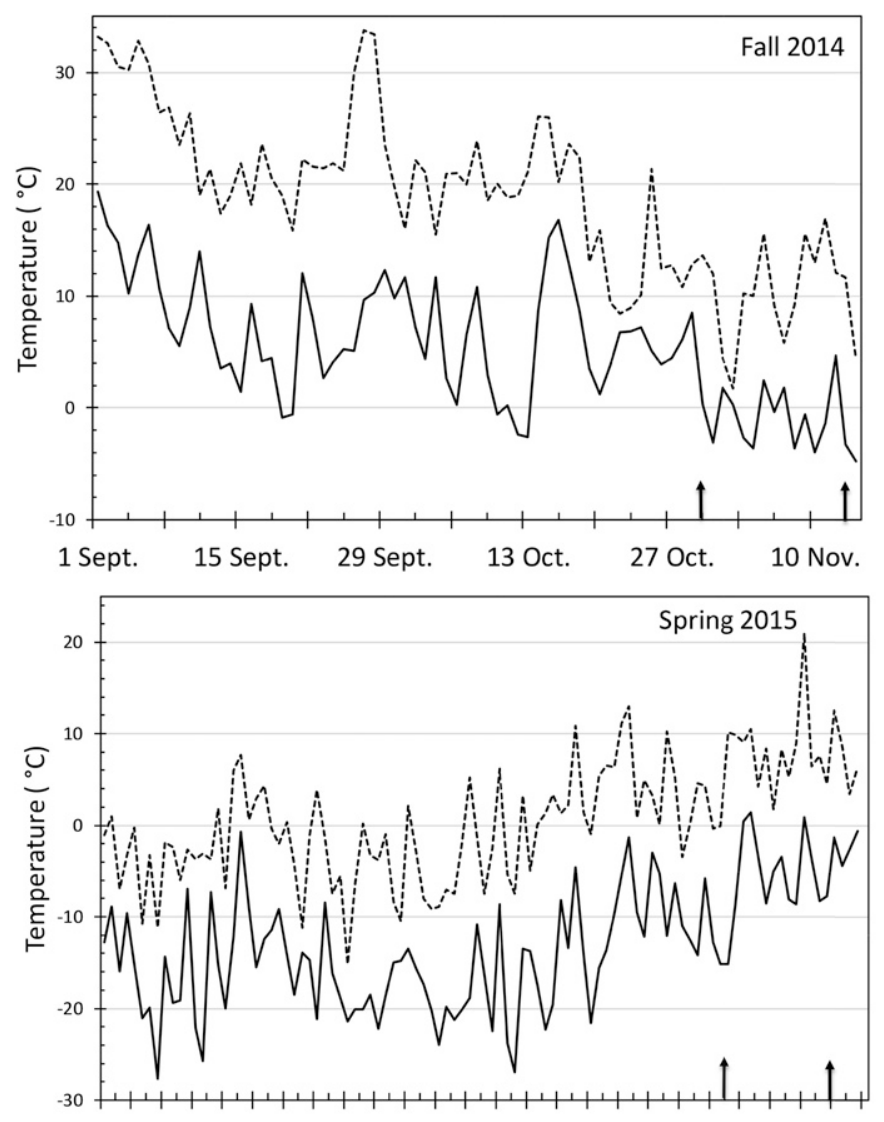

1 Jan. 15 Jan. 29 Jan. 12 Feb. 26 Feb. 11 Mar. 25 Mar. 9 Apr

$$
\text { Date -Min ----Max }
$$

Fig. 3. Minimum and maximum air temperatures at the rootstock orchard in the weeks preceding low temperature tolerance measurements in Expt. 2. The arrows along the $\mathrm{x}$-axis indicate measurement dates. shoot sections exposed to $-20^{\circ} \mathrm{C}$. Therefore, unfrozen control data were not included in the regression analysis for Vineland selections, as it was likely an artifact of extended storage of these controls. Reading glasses with +3.00 strength and lightemitting diode lighting were used to improve visual observation of tissue browning.

Data ANALYSIS. Data were analyzed using SAS (version 9.1; SAS Institute, Cary, NC) PROC NLIN and the Newton method to estimate the three parameters of an adjusted logistic sigmoid function, $y=B \max /\left[1+\mathrm{e}^{\mathrm{b}(\mathrm{TI}-\mathrm{x}}\right]$ where $\mathrm{y}$ is the amount of brown tissue and $\mathrm{x}$ is temperature (Repo and Lappi, 1989). Bmax is the upper asymptote of the function (Fig. 1) and corresponds with the maximum level of browning measured at the lowest temperature. Parameter b is the slope at the inflection point, which corresponds with the greatest increase in browning with decrease in temperature. The temperature at the inflection point, TI, in some cases, is considered the level of low temperature tolerance. All three points of the equation were calculated using PROC NLIN. Because of the large variability of estimates for the inflection points, differences in genotypes were based on Bmax and their 95\% confidence intervals. In Fall 2014 and Spring 2015, significant browning difference between October and November, and between March and April, but within a genotype and temperature, was based on analysis of variance partial sums of squares using the GLM procedure.

\section{Results}

Ambient outdoor temperatures. Air temperature remained above freezing in the weeks preceding 22 Oct. 2013, the first measurement date in Expt. 1, but fell below freezing, $-3.7{ }^{\circ} \mathrm{C}$, before 29 Oct. and dropped to $-7.4{ }^{\circ} \mathrm{C}$ the morning of 29 Oct. (Fig. 2). Daily maximum temperatures were

Table 1. Maximum xylem browning rating (Bmax) and temperature at the inflection point (TI) of the temperature response curves of 2year-old shoots of apple rootstock genotypes in Oct. 2013, Jan. 2014, and Apr. 2014.

\begin{tabular}{|c|c|c|c|c|c|c|}
\hline \multirow[b]{2}{*}{ Genotype } & \multicolumn{2}{|c|}{ Oct. 2013} & \multicolumn{2}{|c|}{ Jan. 2014} & \multicolumn{2}{|c|}{ Apr. 2014} \\
\hline & Bmax & TI $\left({ }^{\circ} \mathrm{C}\right)$ & Bmax & TI $\left({ }^{\circ} \mathrm{C}\right)$ & Bmax & TI $\left({ }^{\circ} \mathrm{C}\right)$ \\
\hline 'M.7' & $2.0 \mathrm{c}$ & $<-40$ & $6.6 \mathrm{a}$ & -34.9 & $8.4 \mathrm{ab}$ & $-20.0 \mathrm{c}$ \\
\hline ‘M.9' & $2.8 \mathrm{bc}^{\mathrm{z}}$ & -27.5 & $3.7 \mathrm{~b}$ & $<-40$ & $5.5 \mathrm{~b}$ & $-32.0 \mathrm{abc}$ \\
\hline 'G.30' & $5.3 \mathrm{~b}$ & -15.0 & $-\mathrm{y}$ & - & $7.4 \mathrm{ab}$ & $-19.7 \mathrm{c}$ \\
\hline 'G.41' & $4.3 \mathrm{abc}$ & -36.0 & $3.8 \mathrm{ab}$ & -33.0 & $7.4 \mathrm{ab}$ & $-20.9 \mathrm{c}$ \\
\hline 'G.214' & $7.6 \mathrm{a}$ & -36.2 & $1.0 \mathrm{abc}$ & $<-40$ & $8.0 \mathrm{ab}$ & $-28.8 \mathrm{a}$ \\
\hline 'G.814' & $4.1 \mathrm{~b}$ & -16.8 & $1.0 \mathrm{c}$ & $<-40$ & $8.4 \mathrm{ab}$ & $-20.0 \mathrm{c}$ \\
\hline 'G.935' & $6.0 \mathrm{ab}$ & -30.2 & $1.9 \mathrm{c}$ & -40 & $8.2 \mathrm{ab}$ & $-24.6 b$ \\
\hline G.3902 & $3.7 \mathrm{~b}$ & -20.0 & $2.5 \mathrm{abc}$ & $<-40$ & $6.8 \mathrm{ab}$ & $-29.7 \mathrm{a}$ \\
\hline G.4011 & $1.7 \mathrm{c}$ & $<-40$ & $1.7 \mathrm{c}$ & $<-40$ & $7.9 \mathrm{ab}$ & $-26.2 \mathrm{ab}$ \\
\hline G.4013 & $8.0 \mathrm{ab}$ & -30.4 & $1.7 \mathrm{c}$ & $<-40$ & $8.5 \mathrm{ab}$ & $-25.0 \mathrm{~b}$ \\
\hline G.4292 & $3.0 \mathrm{c}$ & -23.4 & $1.4 \mathrm{c}$ & $<-40$ & $8.5 \mathrm{ab}$ & $-20.5 c$ \\
\hline G.5087 & $1.8 \mathrm{c}$ & $<-40$ & $1.8 \mathrm{c}$ & $<-40$ & $6.8 \mathrm{~b}$ & $-25.6 b$ \\
\hline G.5257 & $4.4 \mathrm{~b}$ & -14.9 & $1.8 \mathrm{bc}$ & $<-40$ & $8.5 \mathrm{ab}$ & $-20.9 c$ \\
\hline V.5 & $2.8 \mathrm{c}$ & -20.6 & $3.6 \mathrm{abc}$ & $<-40$ & $9.1 \mathrm{a}$ & $-24.2 \mathrm{~b}$ \\
\hline V.6 & $4.1 \mathrm{~b}$ & -15.0 & $6.4 \mathrm{abc}$ & -36.0 & $7.2 \mathrm{ab}$ & $-26.2 \mathrm{abc}$ \\
\hline V.7 & $4.2 \mathrm{~b}$ & -20.4 & $5.7 \mathrm{abc}$ & -37.5 & $7.5 \mathrm{ab}$ & $-25.4 a b c$ \\
\hline
\end{tabular}

Bmax is the upper asymptote and TI is the temperature at the steepest slope of the logistic function $\mathrm{y}=\operatorname{Bmax} /\left[1+\mathrm{e}^{\mathrm{b}(\mathrm{TI}-\mathrm{x})}\right]$, where $\mathrm{y}=$ the amount brown tissue and $\mathrm{x}=$ temperature.

${ }^{\mathrm{z}}$ Means separation within a column by $95 \%$ confidence interval.

${ }^{\mathrm{y}}$ Genotype not measured. 
above freezing before both October measurement dates with $22.8^{\circ} \mathrm{C}$ and $18.7^{\circ} \mathrm{C}$ being the maximum temperatures in the 10 preceding days, respectively. Before the Jan. 2014 measurement date, both the minimum and maximum air temperature were below freezing for several days, with a low temperature of $-25.1{ }^{\circ} \mathrm{C}$ recorded 1 Jan. A rise in maximum temperatures occurred in the $7 \mathrm{~d}$ before the April measurement date with a high of $14.1^{\circ} \mathrm{C}$ and a minimum of $-5.6^{\circ} \mathrm{C}$.

In mid-Oct. 2014, minimum air temperatures fell below freezing for several days and reached a minimum of $-2.6^{\circ} \mathrm{C}$ on 13 Oct., but then remained above freezing for the 2 weeks before the October measurement date (Fig. 3). Before the November measurement date, the minimum temperature fell to $-4.0^{\circ} \mathrm{C}$ on 10 Nov. During Winter 2015, minimum temperatures fell below $-25{ }^{\circ} \mathrm{C}$ on $3 \mathrm{~d}$ and reached a low of $-27.6^{\circ} \mathrm{C}$ on 8 Jan. Minimum air temperatures were below freezing during the period from January through the March measurement date. Before the April measurement date, temperatures increased and reached a high of $21.0^{\circ} \mathrm{C}$ on 3 April. On most days in this period, however, daily minimums were below freezing, with a low of $-8.6^{\circ} \mathrm{C}$ on $2 \mathrm{Apr}$.

EXPt. 1: Xylem injury. The amount of xylem injury, as indicated by browning discoloration at the coldest temperature (Bmax), varied substantially from October to April (Table 1; Fig. 4). Genotypes are listed in the order of cultivars first followed by advanced selections. Injury was most severe in April, mild in January, and intermediate in October. In October, the xylem Bmax was low in some genotypes, in which case the TI was not a good estimate of mortality, but an estimate of the temperature that caused partial browning of the tissue. In January, the Bmax was less than $30 \%$ in most genotypes after exposure to $-40{ }^{\circ} \mathrm{C}$, and was not likely to be lethal. In April when the xylem Bmax was severe, the TI likely represented a meaningful estimate of lethal temperature for xylem.

In October, minimal difference occurred in injury between the two measurement dates, so data were pooled for analysis. The xylem Bmax was highly variable among genotypes, but the TI was not (Table 1; Fig. 4). 'M.7', 'M.9', G.4011, G.4292,
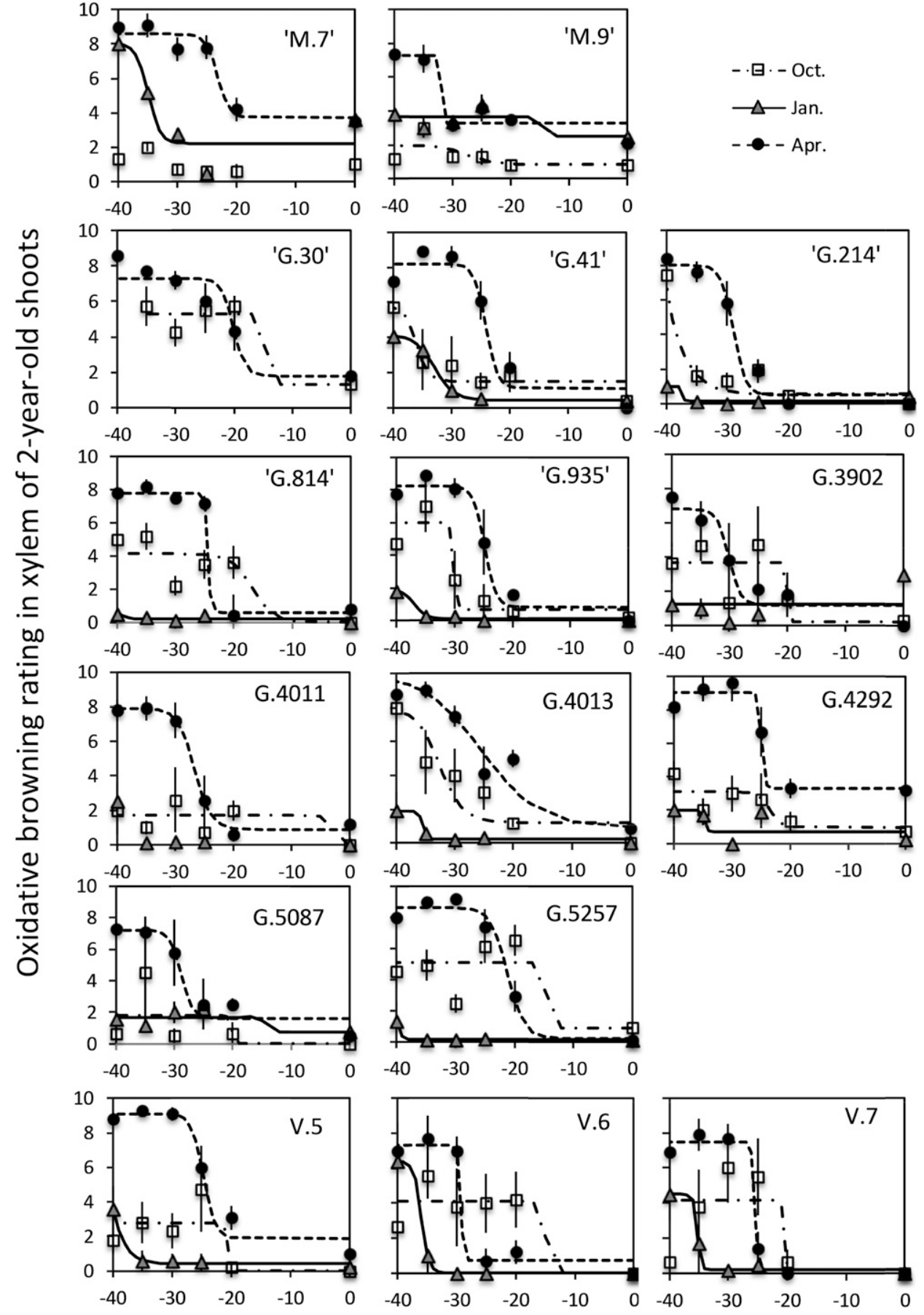

Temperature $\left({ }^{\circ} \mathrm{C}\right)$

Fig. 4. Xylem browning in 2-year-old shoot pieces in seven apple rootstock cultivars and nine advanced selections exposed to subfreezing temperatures in Oct., Jan., and Apr. 2013-14. Browning was rated as a proportion of tissue that was brown on a scale of 0 (indicating none) to 10 (indicating complete discoloration).

G.5087, and V.5 displayed little to no injury at temperatures as low as $-40{ }^{\circ} \mathrm{C}$. In these genotypes, the xylem Bmax was not significantly different from that found in the genotype with the lowest level of injury, G.4011. In these genotypes, less than $30 \%$ of the xylem tissue had been discolored at the coldest temperature. An intermediate level of injury occurred in 'G.30', 'G.814', G.3902, G.5257, V.6, and V.7 that was significantly lower than in 'G.214', which had pronounced browning 
at $-40^{\circ} \mathrm{C}$. The xylem Bmax in 'G.41', 'G.935', and G.4013 was not significantly different from the Bmax in ' $G .214$ '. Although injury at $-40^{\circ} \mathrm{C}$ was moderate to severe in ' $\mathrm{G} .41$ ', ' $\mathrm{G} .214^{\prime}$ ', and 'G.935', injury was mild at temperatures of $-30{ }^{\circ} \mathrm{C}$ and higher. In contrast, 'G.30', 'G.814', G.3902, G.5257, V.6, and V.7 displayed moderate to severe xylem injury at temperatures as high as $-20^{\circ} \mathrm{C}$. The amount of browning within the range of the TI was highly variable among shoots within a genotype, so genotypic differences in the TI were not significant.

Greater xylem hardiness had developed by January, when several genotypes, 'G.814', 'G.935', G.4011, G.4013, G.4292, and G.5087, displayed very little injury at $-40{ }^{\circ} \mathrm{C}$ (Table 1; Fig. 4), and had significantly lower Bmax than in 'M.7' and 'M.9'. 'G.214' also had a low Bmax, but was similar to other genotypes due to a high degree of variability. 'M.7' had the highest Bmax that was higher than that of 'M.9', but similar to those of other genotypes. The Bmax in G.3902, V.5, V.6, and V.7 was similar to the Bmax in all other genotypes. No difference in TI occurred between genotypes in January.

In April, all genotypes had moderate to severe xylem injury at $-40{ }^{\circ} \mathrm{C}$ and a TI of $-32{ }^{\circ} \mathrm{C}$ or higher (Table 1; Fig. 3 ). V.5 had the greatest xylem Bmax, although most genotypes had values similar to V.5, except for 'M.9' and G.5087, which had a lower Bmax. Genotypic variation occurred in the TI, and 'G.214', G.3902, and G.4011 had TI values that were colder than those of 'M.7', 'G.30', 'G.41', 'G.814', G.4292, and G.5257. An intermediate TI occurred in 'G.935', G.4013, and G.5087. 'M.9' had the lowest TI, but due to variability in the amount of browning, it was not significantly different from the TI in other genotypes.

Expt. 1: Phloem injury. In most genotypes, phloem was less hardy in October than in January or April, and remained nearly as hardy in April as it was in January (Table 2; Fig. 5). Phloem injury in October varied from about $20 \%$ to $80 \%$ of the

Table 2. Maximum phloem browning rating (Bmax) and temperature at the inflection point (TI) of the temperature response curves of 2year-old shoots of apple rootstock genotypes in Oct. 2013, Jan. 2014, and Apr. 2014.

\begin{tabular}{|c|c|c|c|c|c|c|}
\hline \multirow[b]{2}{*}{ Genotype } & \multicolumn{2}{|c|}{ Oct. 2013} & \multicolumn{2}{|c|}{ Jan. 2014} & \multicolumn{2}{|c|}{ Apr. 2014} \\
\hline & Bmax & TI $\left({ }^{\circ} \mathrm{C}\right)$ & Bmax & TI $\left({ }^{\circ} \mathrm{C}\right)$ & Bmax & TI $\left({ }^{\circ} \mathrm{C}\right)$ \\
\hline 'M.7' & $4.7 \mathrm{~b}$ & -12.4 & $0.0 \mathrm{c}$ & $<-40$ & $0.1 \mathrm{c}$ & $<-40$ \\
\hline ‘M.9’ & $1.6 \mathrm{c}^{\mathrm{z}}$ & -29.4 & $0.2 \mathrm{c}$ & $<-40$ & $0.1 \mathrm{c}$ & $<-40$ \\
\hline ‘G.30’' & $5.9 \mathrm{~b}$ & -20.4 & $-\mathrm{y}$ & - & $0.0 \mathrm{c}$ & $<-40$ \\
\hline ‘G.41' & $6.6 \mathrm{ab}$ & -20.6 & $4.2 \mathrm{a}$ & -35.8 & $4.0 \mathrm{a}$ & -35.0 \\
\hline 'G.214' & $6.2 \mathrm{~b}$ & -20.4 & $2.1 \mathrm{abc}$ & $<-40$ & $0.9 \mathrm{~b}$ & $<-40$ \\
\hline 'G.814' & $7.9 \mathrm{a}$ & -20.6 & $2.4 \mathrm{ab}$ & $<-40$ & $0.9 \mathrm{~b}$ & $<-40$ \\
\hline 'G.935' & $7.4 \mathrm{ab}$ & -25.0 & $0.3 \mathrm{c}$ & $<-40$ & $0.0 \mathrm{c}$ & $<-40$ \\
\hline G.3902 & $5.0 \mathrm{~b}$ & -19.9 & $0.8 \mathrm{bc}$ & $<-40$ & $3.2 \mathrm{ab}$ & -35.3 \\
\hline G.4011 & $6.2 \mathrm{ab}$ & -19.9 & $1.5 \mathrm{~b}$ & $<-40$ & $4.2 \mathrm{a}$ & -35.0 \\
\hline G.4013 & $7.4 \mathrm{a}$ & -15.1 & $2.4 \mathrm{ab}$ & $<-40$ & $4.5 \mathrm{abc}$ & -39.4 \\
\hline G.4292 & $5.4 \mathrm{~b}$ & -19.9 & $1.9 \mathrm{ab}$ & $<-40$ & $4.8 \mathrm{a}$ & -36.1 \\
\hline G.5087 & $4.7 \mathrm{~b}$ & $>-20.0$ & $2.4 \mathrm{ab}$ & $<-40$ & $1.8 \mathrm{~b}$ & -39.0 \\
\hline G.5257 & $4.8 \mathrm{~b}$ & -19.3 & $2.0 \mathrm{ab}$ & $<-40$ & $0.8 \mathrm{~b}$ & -40.0 \\
\hline V.5 & $4.9 \mathrm{~b}$ & -21.5 & $0.3 \mathrm{c}$ & $<-40$ & $3.0 \mathrm{abc}$ & -39.0 \\
\hline V.6 & $5.2 \mathrm{~b}$ & -20.4 & $1.2 \mathrm{bc}$ & $<-40$ & $1.6 \mathrm{abc}$ & $<-40$ \\
\hline V.7 & $5.7 \mathrm{~b}$ & -20.3 & $1.4 \mathrm{abc}$ & $<-40$ & $3.9 \mathrm{ab}$ & -38.0 \\
\hline
\end{tabular}

Bmax is the upper asymptote and TI is the temperature at the steepest slope of the logistic function $\mathrm{y}=\mathrm{Bmax} /\left[1+\mathrm{e}^{\mathrm{b}(\mathrm{TI}-\mathrm{x})}\right]$, where $\mathrm{y}=$ the amount brown tissue and $\mathrm{x}=$ temperature.

${ }^{\mathrm{z}}$ Means separation within a column is by $95 \%$ confidence interval.

${ }^{\mathrm{y}}$ Genotype not measured. tissue compared with $0 \%$ to $40 \%$ in January and $0 \%$ to $50 \%$ in April. In addition, TI ranged from -15 to $-20{ }^{\circ} \mathrm{C}$ in most genotypes in October compared with -35 to $-40{ }^{\circ} \mathrm{C}$ in January and April.

Genotypic variation in phloem injury occurred in October. The phloem Bmax was greatest in 'G.814', and was similar to injury in 'G.41', 'G.935', G.4011, and G.4013. The Bmax was lowest in 'M.9' and intermediate in other genotypes. The TI was also lowest in 'M.9', intermediate in 'G.935', and $-22^{\circ} \mathrm{C}$ or higher in other genotypes, but was not significantly different among genotypes.

In January, phloem injury was mild, and the TI was below $-40{ }^{\circ} \mathrm{C}$ for most genotypes. 'G.41' had a phloem Bmax that was greater than those of 'M.7', 'M.9', 'G.935', G.3902, G.4011, V.5, and V.6, but not greater than those of other genotypes. Significant genotypic variation in the TI was not observed in January.

In April, phloem injury was low to moderate (Table 2; Fig. 5). The phloem Bmax was greatest in G.4292 and was significantly greater than in 'M.7', 'M.9', 'G.30', 'G.214', 'G.814', 'G.935', G.5087, and G.5257. The TI for phloem injury in April was -35 to $-38^{\circ} \mathrm{C}$ in genotypes with the greatest injury and $<-40{ }^{\circ} \mathrm{C}$ in genotypes with minimal injury. Genotypic variation in TI was not observed in April.

Expt. 1: Cambial inJury. Low temperature tolerance of the cambium was not measured in October. Cambial injury at $-40{ }^{\circ} \mathrm{C}$ was mild to severe in January depending on genotype and was severe in all genotypes in April (Table 3). Temperature at the inflection point was -29 to $-40{ }^{\circ} \mathrm{C}$ in January and increased to -25 to $-35^{\circ} \mathrm{C}$ in April.

Genotypic variation occurred in the cambial Bmax in January (Table 3; Fig. 6). The Bmax was greatest in 'M.7', and was similar to that of 'G.214', 'G.935', G.4011, G.4292, G.5257, V.5, and V.7. However, the cambial Bmax in 'G.935', V.5, and V.7 was highly variable among samples and not different from any other genotype. Bmax in 'M.9', 'G.41', 'G.814', G.3902, G.4013, G.5087, and V.6 was lower than in 'M.7'. The TI ranged from a high of $-29^{\circ} \mathrm{C}$ in ' $\mathrm{G} .41$ ' to a low of $-40{ }^{\circ} \mathrm{C}$ in 'M.9', G.3902, and G.4292, but did not vary among genotypes.

In April, the Bmax was severe and did not vary with genotype. Cambial TI in 'M.9', 'G.41', G.4011, and V.7 was highly variable such that TI did not differ from other genotypes. The lowest TI occurred in 'G.30', 'G.214', and G.3902, significantly lower than in most other genotypes. 'M.7', 'G.814', and G.5257 had the highest TI, which was significantly higher than in most other genotypes.

EXPT. 2: XYLeM INJURY. In Fall 2014, xylem injury in October was more severe than in November in most genotypes (Fig. 7). Severe injury occurred at $-20{ }^{\circ} \mathrm{C}$ and colder in October, and in November injury was generally not severe until a temperature of $-25^{\circ} \mathrm{C}$. A reduction in the amount of browning occurred in most of the genotypes in the 2 weeks between the October and November measurement dates. Because the amount of injury was highly variable within a temperature, differences in TI were not significant, although they ranged from -15 to $-30{ }^{\circ} \mathrm{C}$ in October. In November, TI varied from a high of $-20{ }^{\circ} \mathrm{C}$ to a low of $-35^{\circ} \mathrm{C}$, indicating a general increase in hardiness of $\approx 5^{\circ} \mathrm{C}$. In March and April, xylem injury was minimal at $-40{ }^{\circ} \mathrm{C}$. A small increase in the xylem Bmax occurred in some genotypes from March to April. Because browning occurred in less than $20 \%$ of the xylem 


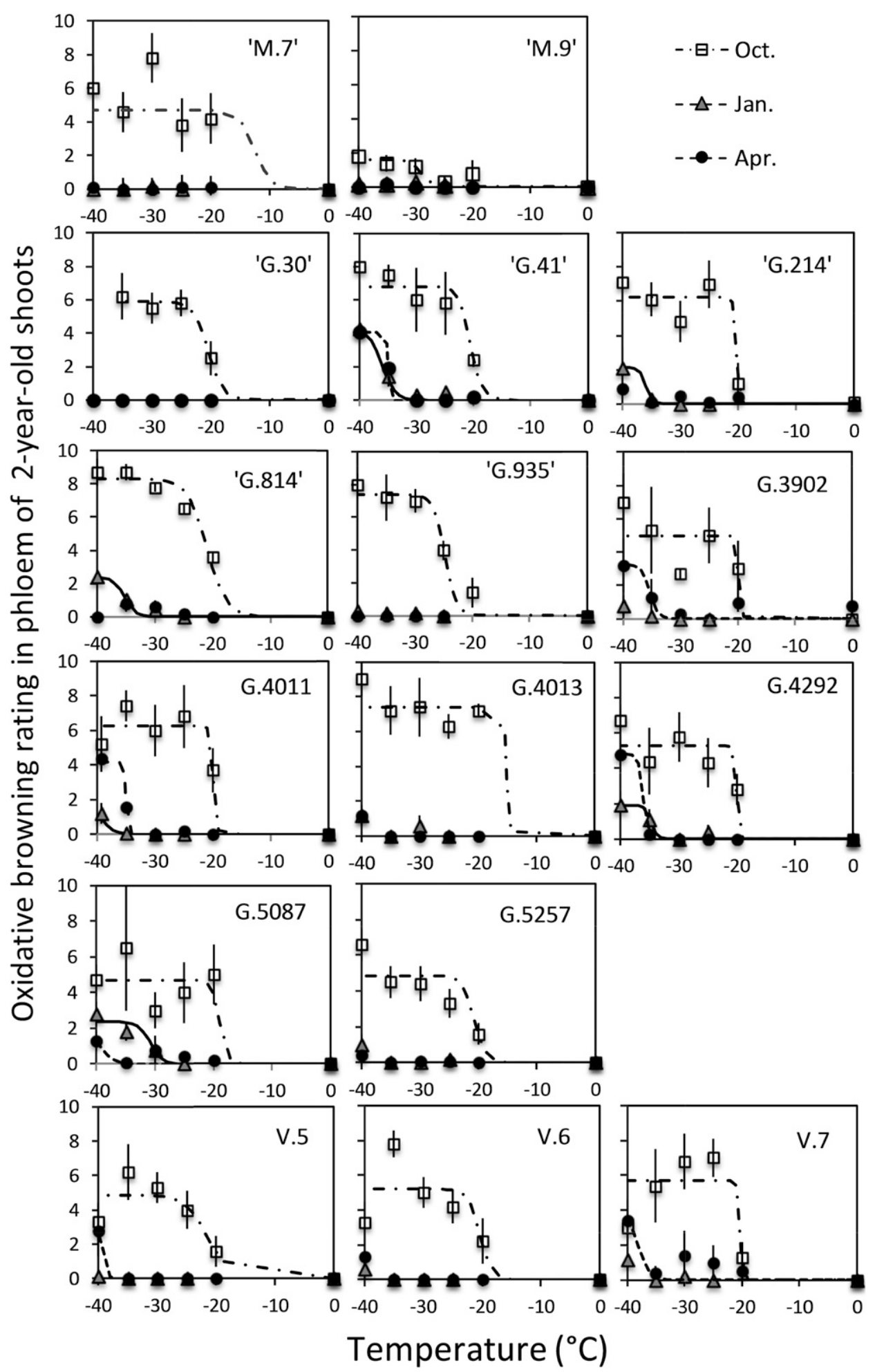

Fig. 5. Phloem browning in 2-year-old shoot pieces in seven apple rootstock cultivars and nine advanced selections exposed to subfreezing temperatures in Oct., Jan., and Apr. 2013-14. Browning was rated as a proportion of tissue that was brown on a scale of 0 (indicating none) to 10 (indicating complete discoloration).

than in 'B.9', 'M.9', 'G.814', 'G.935', G.3902, G.4011, G.4013, G.4292, G.5087, and G.5257. The lowest Bmax occurred in 'G.935', G.3902, G.4011, G.5087, and G.5257, which had significantly lower Bmax than the other genotypes. The Bmax of 'B.9', 'M.9', 'G.30', 'G.41', G.4013, and G.4292 was intermediate. In October, the TI ranged from a high of $-15{ }^{\circ} \mathrm{C}$ in 'M.9', 'G.814' and G.4292 to a low of $-30{ }^{\circ} \mathrm{C}$ in 'G.41'. In November, the Bmax of 'G.30', 'G.41', G.4292, G.5257, and V.7 was greater than that of 'B.9', 'G.214', and G.4011. In 'G.935' and G.5087, the Bmax could not be estimated by the nonlinear regression model, but injury was low at -30 and $-35{ }^{\circ} \mathrm{C}$. The lowest Bmax occurred in G.4011, and this was similar to the Bmax of 'B.9', 'M.9', 'G.214', and G.4013. The xylem Bmax in G.3902 and V.6 was not significantly different from the Bmax of other genotypes. In November, the TI ranged from a low below $-35{ }^{\circ} \mathrm{C}$ in G.5087 to a high of $-20{ }^{\circ} \mathrm{C}$ in 'G.41', G.4292, and V.5.

An increase in xylem hardiness, measured as a reduction in the Bmax from October to November, occurred in 'M.9', 'B.9', 'G.214', V.5, and V.7, but no change in Bmax occurred in other genotypes. A reduction in xylem injury within a temperature between measurement dates was interpreted as an increase in cold hardiness, and the level injury was lower in November than in October in all genotypes except 'G.41' and 'G.3902' (Fig. 7).

Genotypic differences in xylem Bmax did not occur in March. In April, very little injury occurred in 'M.9', which had the lowest Bmax. Compared with that of 'M.9', the Bmax was significantly greater in G.4013, G.4292, G.5257, and V.5, but was similar to the Bmax of other genotypes. A small increase in xylem Bmax occurred from March to April in G.4013, G.4292, G.5257, and V.5. Due to a low level of injury in March and April, the TI is unlikely to be representative of the

tissue in all genotypes that were tested, the TI was not meaningful and is not reported for Spring 2015.

Genotypic variation occurred in the xylem Bmax in October and November (Table 4; Fig. 7). In October, 'G.214', V.5, V.6, and V.7 had the greatest Bmax, which was significantly greater lethal temperature and is not reported.

Expt. 2: Phloem InJury. Phloem injury was generally more severe in October than in November (Table 5; Fig. 8). The phloem Bmax was greater than 5.0 in most genotypes, and the TI ranged from -20 to $-31^{\circ} \mathrm{C}$ in October. By mid November, 
Table 3. Maximum cambial browning rating (Bmax) and temperature at the inflection point (TI) of the temperature response curves of 2 year-old shoots of apple rootstock genotypes in Jan. and Apr. 2014.

\begin{tabular}{|c|c|c|c|c|}
\hline \multirow[b]{2}{*}{ Genotype } & \multicolumn{2}{|c|}{ Jan. 2014} & \multicolumn{2}{|c|}{ Apr. 2014} \\
\hline & Bmax & $\mathrm{TI}\left({ }^{\circ} \mathrm{C}\right)$ & $\overline{B \max }$ & $\mathrm{TI}\left({ }^{\circ} \mathrm{C}\right)$ \\
\hline 'M.7' & $8.0 \mathrm{a}$ & -34.6 & 8.3 & $-25.0 \mathrm{~d}$ \\
\hline ‘M.9’ & $0.2 \mathrm{c}^{\mathrm{z}}$ & $<-40$ & 8.1 & $-34.6 \mathrm{a}-\mathrm{c}$ \\
\hline 'G.30' & $-\mathrm{y}$ & - & 8.0 & $-32.2 b c$ \\
\hline 'G.41' & $2.2 \mathrm{~b}$ & -29.2 & 8.0 & $-29.4 a-c$ \\
\hline 'G.214' & $4.2 \mathrm{a}$ & -36.0 & 9.5 & $-33.9 \mathrm{~b}$ \\
\hline 'G.814' & $1.6 \mathrm{~b}$ & -34.8 & 8.8 & $-25.5 \mathrm{~d}$ \\
\hline 'G.935' & $1.8 \mathrm{abc}$ & -36.5 & 9.6 & $-30.3 \mathrm{c}$ \\
\hline G.3902 & $1.6 \mathrm{bc}$ & $<-40$ & 8.4 & $-34.7 \mathrm{a}$ \\
\hline G.4011 & $5.7 \mathrm{ab}$ & -35.3 & 8.7 & $-24.8 \mathrm{a}-\mathrm{d}$ \\
\hline G.4013 & $2.7 \mathrm{~b}$ & -36.5 & 9.9 & $-28.9 \mathrm{c}$ \\
\hline G.4292 & $3.5 \mathrm{ab}$ & $<-40$ & 8.2 & $-29.1 \mathrm{c}$ \\
\hline G.5087 & $3.4 \mathrm{~b}$ & -31.9 & 8.5 & $-29.5 \mathrm{c}$ \\
\hline G.5257 & $5.9 \mathrm{ab}$ & -35.4 & 9.3 & $-22.7 \mathrm{~d}$ \\
\hline V.5 & $4.0 \mathrm{abc}$ & -39.1 & 8.9 & $-30.0 \mathrm{c}$ \\
\hline V.6 & $2.0 \mathrm{bc}$ & -37.0 & 8.6 & $-29.1 \mathrm{c}$ \\
\hline V.7 & $7.4 \mathrm{abc}$ & -37.4 & 7.4 & $-27.3 \mathrm{a}-\mathrm{c}$ \\
\hline
\end{tabular}

Bmax is the upper asymptote and TI is the temperature at the steepest slope of the logistic function $y=B \max /\left[1+e^{b(T I-x)}\right]$, where $y=$ the amount brown tissue and $\mathrm{x}=$ temperature.

${ }^{z}$ Means separation within a column is by $95 \%$ confidence interval.

${ }^{\mathrm{y}}$ Genotype not measured.

the phloem Bmax was less than 5.0 in half of the genotypes, and the TI ranged from -20 to $-38{ }^{\circ} \mathrm{C}$. In March, shoots had considerable phloem cold hardiness and a low phloem Bmax. Six of the 10 genotypes that were measured in March showed an increase in phloem Bmax in April, but phloem injury was not severe in any genotype. Because of the low amount of phloem injury in March and April, the TI is unlikely to be representative of lethal temperature and is not reported.

Genotypic differences in phloem Bmax and the TI occurred in October (Table 5; Fig. 8). In October, the phloem Bmax was lower in 'G.41' and V.7 than in other genotypes except for 'B.9', 'M.9', G.3902, and G.5087. Greatest Bmax occurred in G.4013, which was similar to the Bmax of 'G.30', G.4292, and V.6. Phloem TI was lowest in 'G.41', which was lower than that of 'G.214', 'G.814', 'G.935', G.3902, G.4292, G.5087, and V.5, all of which had a TI of $-25{ }^{\circ} \mathrm{C}$ and higher. The TI in G.4011, G.4013, V.6, and V.7 did not differ significantly from those of other genotypes.

In November, the phloem Bmax was lower in V.5, V.6, and V.7 than in other genotypes (Table 5; Fig. 8). In contrast, G.4013 had a greater phloem Bmax than G.4292, G.5257, and Vineland selections. In ' G.41', the response was curvilinear and the TI could not be estimated, but injury was slight to moderate at temperatures higher than $-35{ }^{\circ} \mathrm{C}$ and injury at $-35{ }^{\circ} \mathrm{C}$ appeared similar to 'B.9', 'M.9' and other Geneva genotypes. The TI ranged from a low of $-38^{\circ} \mathrm{C}$ in 'B.9' to a high of $-20^{\circ} \mathrm{C}$ in G.4011. The TI was lower in 'M.9', 'G.30', 'G.814' and V.7 than in 'G.214', 'G.935', G.4011, G.4013, G.4292, and G.5257.

A reduction in the phloem Bmax occurred from October to November in 'G.214', G.4011, G.4013, G.4292, G.5257, V.5, V.6, and V.7, but a significant reduction did not occur within other genotypes (Table 5; Fig. 8). A reduction in injury at temperatures in the range of -20 to $-35^{\circ} \mathrm{C}$ occurred in ' $\mathrm{G} .41$ ', 'G.30', 'G.214', 'G.814', 'G.935', G.3902, G.4011, G.4013,
G.4292, G.5257, V.5, V.6, and V.7. No change in phloem Bmax occurred between October and November in 'B.9' or 'M.9', but both had developed hardiness to $-30{ }^{\circ} \mathrm{C}$ by late October. Because phloem browning was highly variable within the temperature range of the TI, a significant reduction in TI from October to November was not detected.

Phloem injury in March was slight in most genotypes, but greater in 'M.9' and 'G.935' than in other genotypes. In April, the phloem Bmax was significantly greater in G.4011 and G.4013 than in other genotypes, except G.5087. G.5257 had less injury than G.4011, G.4013, 'M.9', 'G.935', G.3902, and V.6, but similar injury to other genotypes. Because phloem injury was generally low in March and April, the TI was not meaningful, so temperature response is not graphically presented. An increase in Bmax occurred from to March to April in 'M.9', 'G.814', G.4013, G.4292, V.5, and V.7.

Expt. 2: Cambial inJury. Cambial injury was generally severe in October and November, with no change between the two dates in most genotypes. In March, several genotypes exhibited no injury, and others exhibited slight injury. From March to April, a moderate increase in injury occurred (Table 6; Fig. 9).

In October and November, genotypes varied in cambial Bmax, but not in the TI. In October, 'M.9', 'G.814', 'G.935', G.3902, G.4011, and G.5087 had a lower cambial Bmax than V.5, V.6, and V.7, but a Bmax similar to other genotypes. V.7 had the greatest Bmax, which was similar to those of ' $\mathrm{G} .30$ ', 'G.41', 'G.214', G.4013, and G.4292. In November, G.5087 had the lowest cambial Bmax, which was significantly lower than those of other genotypes except ' $G .935$ '. The Bmax in G.3902 and V.6 did not differ from those of other genotypes. The cambial Bmax was lower in 'M.9', 'G.214', G.4011, and G.4292 than in 'G.41', which had the greatest Bmax. Like 'G.41', the Bmax values were high in 'B.9', 'G.814', G.3902, G.4013, G.5257, V.5, V.6, and V.7. In October, the TI ranged from $-20{ }^{\circ} \mathrm{C}$ in 'M.9' to $-32{ }^{\circ} \mathrm{C}$ in G.3902. In October, the TI ranged from a low of $-30^{\circ} \mathrm{C}$ in 'B.9', G.3902, V.5, V.6, and V.7 to a high of $-19^{\circ} \mathrm{C}$ in G.4292.

A reduction in the cambial Bmax from October to November occurred in 'G.214', G.5087, V.6, and V.7, but not in other genotypes (Table 6; Fig. 9). In most genotypes, injury at -25 and $-30{ }^{\circ} \mathrm{C}$ was less severe in November than in October, but not in 'G.41', G.3902, G.4011, and G.5087. From October to November, this reduction in injury at -25 and $-30{ }^{\circ} \mathrm{C}$ was most dramatic in V.5, V.6, and V.7.

Injury in the cambium was mild in March and did not differ among genotypes (Table 6; Fig. 9). In April, genotypic differences in the Bmax were small, although G.5087 had greater injury than 'B.9', 'M.9', 'G.814', 'G.935', G.3902, G.4011, and G.4292, and 'B.9' had less injury than most other genotypes. The cambial Bmax increased from March to April in 'M.9', G.4013, G.4292, G.5257, V.5, and V.7.

\section{Discussion}

Fall hardiness. Cold acclimation of apple rootstock genotypes was evident as a reduction in Bmax, such that some tissue within the shoot remained uninjured at the coldest test temperatures of -35 and $-40{ }^{\circ} \mathrm{C}$. In many shoots, injury of the inner xylem occurred at higher temperatures than in the outer xylem, indicating that the younger xylem tissue was hardier than older xylem. Consequently, the hardiness of a branch 


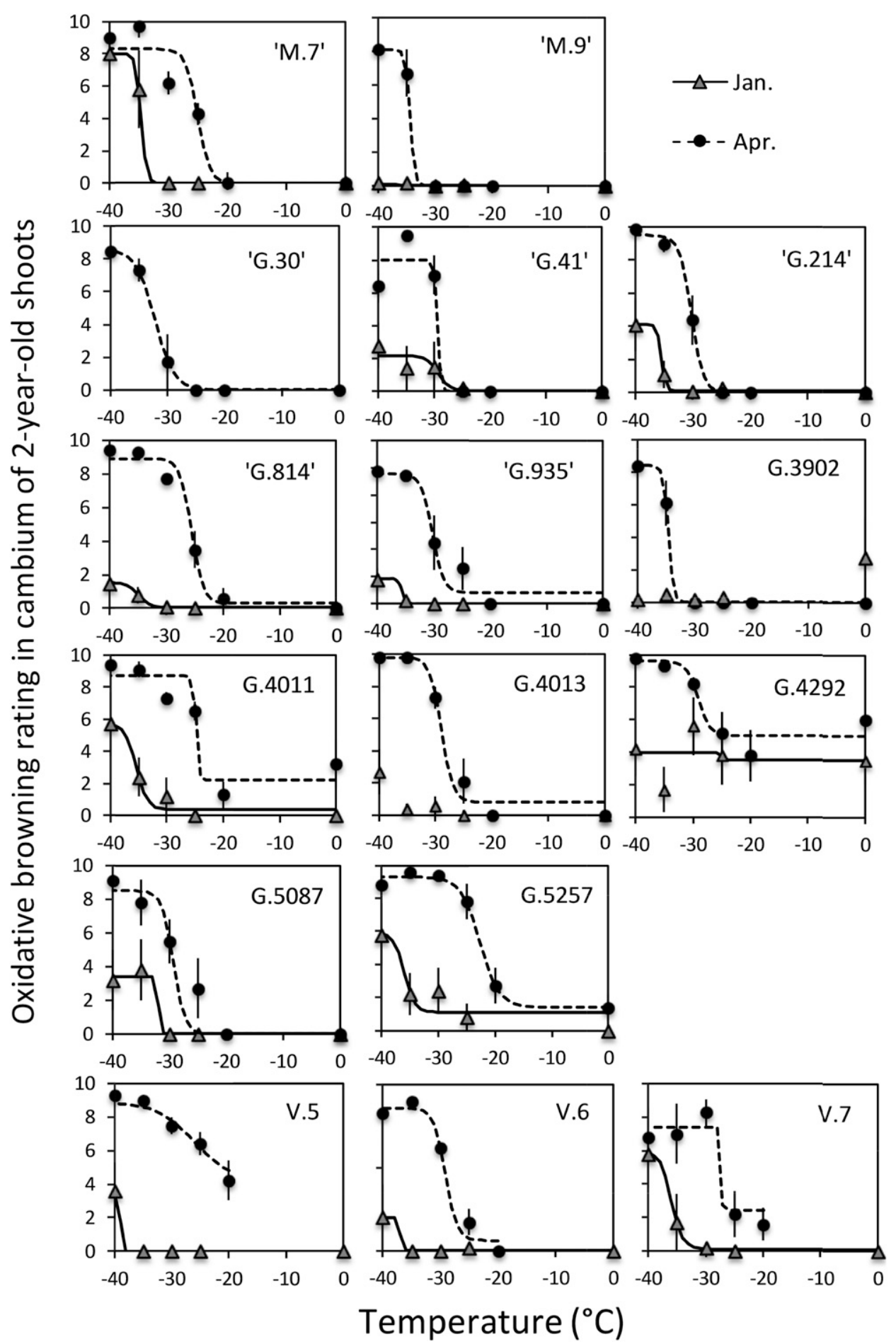

Fig. 6. Cambial browning in 2-year-old shoot pieces in seven apple rootstock cultivars and nine advanced selections exposed to subfreezing temperatures in Jan. and Apr. 2014. Browning was rated as a proportion of tissue that was brown on a scale of 0 (indicating none) to 10 (indicating complete discoloration). and Hampson, 2004; Steinmetz and Hilborn, 1938) is needed for a measurable effect on shoot growth or survival. The occurrence of partial rather than complete injury may indicate low temperature tolerance, particularly in the younger, outer xylem.

In October, partial xylem injury comprising less than $50 \%$ of crosssectional area occurred in many genotypes at -35 to $-40{ }^{\circ} \mathrm{C}$. The genotypes 'M.7', 'M.9', G.4011, G.4292, G.5087, and V.5 displayed partial injury in 2013, and 'G.935', G.4011, and G.5087 displayed partial injury in 2014. These genotypes are less likely to suffer complete xylem damage in the fall than more tender genotypes. 'G.30' had moderate to severe browning at temperatures above $-20{ }^{\circ} \mathrm{C}$ in both years, indicating potential vulnerability. Some genotypes ('G.41' in both years, and 'M.7', 'G.214', and G.4011 in one of the 2 years of testing) had a high Bmax with a low TI, and could suffer injury if temperatures dropped below $-30^{\circ} \mathrm{C}$ in October, an uncommon event in most regions of apple production.

Cold acclimation was also evident as a reduction in the TI to lower temperatures. In some cases, there was a gradual or linear increase in browning as temperature decreased rather than a substantial increase over a narrow temperature range. Xylem parenchyma cells do not die simultaneously at one temperature, but in numerous, small and separate occurrences, and over a range of temperatures (Pramsohler et al., 2012).

Several days of freezing can increase hardiness by several degrees (Mathers and Stushnoff, 2005). This occurred between the October and November measurement dates in 2014 during which most genotypes showed at least one sign of an increase in xylem hardiness including a reduction in the $\mathrm{Bmax}$, a 5 to $10^{\circ} \mathrm{C}$ decrease of the TI, or reduced injury at specific temperatures. The only or limb, a structure with a complex tissue of old and new xylem, may not be described by a single lethal temperature. As in this study, partial xylem browning also occurs in 'Honeycrisp'/'M.9' at $-40{ }^{\circ} \mathrm{C}$, in contrast to the more tender 'Golden Delicious'/'M.9' which has complete xylem browning (Cline et al., 2012). In limbs and trunks of apple, $\approx 50 \%$ browning of xylem cross-sectional area (Domoto et al., 2001; Quamme genotype to show no increase in hardiness during this 2-week period was ' $\mathrm{G} .41$ ', but it was already hardy to $-30{ }^{\circ} \mathrm{C}$ in October. Shoot tissues in apple are hardy to -15 to $-20{ }^{\circ} \mathrm{C}$ following the first stage of acclimation brought on by shortening daylength and cool temperatures (Hong and Sucoff, 1982; Ketchie, 1985), and they can become hardy to $-29{ }^{\circ} \mathrm{C}$ by November (Wildung et al., 1973). Trees in our study displayed 

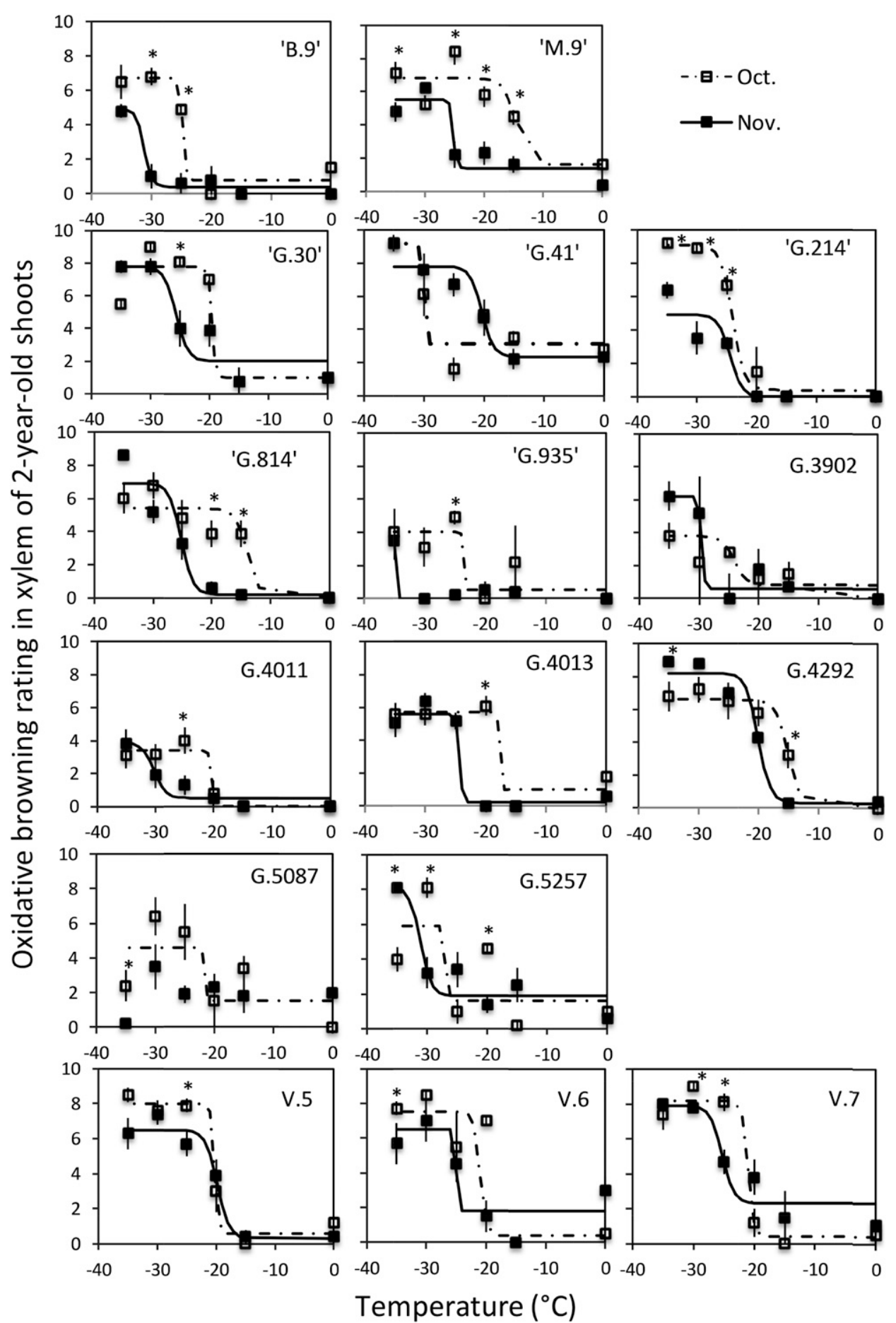

Fig. 7. Xylem browning in 2-year-old shoot pieces in seven apple rootstock cultivars and nine advanced selections exposed to subfreezing temperatures in Oct. and Nov. 2014. Browning was rated as an index whereby index $=$ (proportion of tissue discolored + intensity of discoloration $\times 2$ ) $/ 2$, with proportion of discoloration rated on a scale of 0 indicating none and 10 indicating complete discoloration and degree of darkening using a scale of 0 to 5 , where 0 indicated no browning and 5 indicated dark brown. Asterisks indicate a significant difference in browning between October and November, but within a genotype and temperature.

the level of xylem and phloem hardiness typical of first-stage acclimation by late October and hardiness to -25 to $-30^{\circ} \mathrm{C}$ by early November.

In both years, severe phloem browning occurred at relatively high temperatures in G.4013, indicating the potential for this tissue to be vulnerable to fall freezes. However, this genotype, along with 'G.935', G.4292, V.5, V.6, and V.7, also showed a large reduction in phloem browning during the 2 weeks from Oct. to Nov. 2014. The largest increase in phloem hardiness from October to November occurred in V.5 and V.6. Almost no change occurred in 'B.9', 'M.9', 'G.30', and 'G.41' during this 2 -week period in the fall, but these genotypes had already developed considerable phloem hardiness by late Oct. 2014, as indicated by their low TI. From October to November, most of the Geneva rootstocks exhibited a reduction in Bmax, so the TI was a measure of injury for part of the phloem rather than all. However, the amount of phloem browning that can occur with no impact on growth and survival remains uncertain.

Phloem tissues in apple can be slower than xylem to develop hardiness in early autumn (Quamme et al., 1972), but similar hardiness among xylem, phloem, and cambial tissue have been measured in quince accessions (Einhorn et al., 2011). In Oct. 2013, phloem tissues were less hardy than xylem in some genotypes ('M.7', 'G.41', 'G.214', 'G.814', 'G.935', G.4011, G.4013, and G.5087) rather than in all, based on the higher TI for phloem compared with the xylem. In other genotypes, phloem appeared to have hardiness similar to that of the xylem. In 2014, TI was higher in xylem than in phloem among several genotypes ('B.9', 'M.9', 'G.30', 'G.814', G.4292, V.5, and V.6). In other genotypes, 'G.935', G.3902, G.4011, and G.4013, phloem had a TI similar to, but a Bmax greater than the xylem within each genotype, indicating a mixed degree of acclimation in these tissues.

In October, cambium of 'M.9' was hardy to $-15^{\circ} \mathrm{C}$, but injury was severe at temperatures of $-20{ }^{\circ} \mathrm{C}$ and below, which is similar to previous reports for Malling rootstocks (Embree, 1988). In the fall, cambium of G.4292 appeared to be less hardy than in other genotypes, and may be more likely to suffer injury. Cambium of 'B.9', 'G.41', and G.3902 had the coldest TI, -28 to $-30^{\circ} \mathrm{C}$, and would be less likely than other genotypes to suffer cambial injury in early autumn. The cambial Bmax did not decrease from October to November in most genotypes, but the TI decreased in 'M.9', 'G.935', G.5087, and Vineland 
Table 4. Maximum xylem browning rating (Bmax) and temperature at the inflection point (TI) of the temperature response curves of 2year-old shoots of apple rootstock genotypes in Oct. 2014, Nov. 2014, Mar. 2015, and Apr. 2015.

\begin{tabular}{|c|c|c|c|c|c|c|}
\hline \multirow[b]{2}{*}{ Genotype } & \multicolumn{2}{|c|}{ Oct. 2014} & \multicolumn{2}{|c|}{ Nov. 2014} & \multirow{2}{*}{$\frac{\text { Mar. } 2015}{\text { Bmax }}$} & \multirow{2}{*}{$\frac{\text { Apr. } 2015}{\text { Bmax }}$} \\
\hline & Bmax & TI $\left({ }^{\circ} \mathrm{C}\right)$ & Bmax & $\mathrm{TI}\left({ }^{\circ} \mathrm{C}\right)$ & & \\
\hline ‘B.9' & $6.7 \mathrm{bc}$ & -24.8 & $4.9 \mathrm{~cd}^{*}$ & -31.2 & $-^{\mathrm{x}}$ & $0.8 \mathrm{c}$ \\
\hline ‘M.9’ & $6.8 \mathrm{bc}^{\mathrm{z}}$ & -14.8 & $5.5 \mathrm{bcd}^{*}$ & -25.3 & 0.8 & $0.0 \mathrm{c}^{*}$ \\
\hline ‘G.30’ & $7.8 \mathrm{ab}$ & -19.5 & $6.8 \mathrm{ab}$ & -25.6 & - & $0.9 \mathrm{bc}$ \\
\hline 'G.41' & $6.1 \mathrm{bc}$ & -30.0 & $7.8 \mathrm{ab}$ & -20.3 & - & - \\
\hline 'G.214' & $9.0 \mathrm{a}$ & -24.0 & $4.9 \mathrm{~cd}^{*}$ & -24.4 & 1.0 & - \\
\hline 'G.814' & $5.4 \mathrm{c}$ & -14.0 & $7.0 \mathrm{~b}$ & -25.2 & 0.9 & $1.2 \mathrm{~b}$ \\
\hline 'G.935' & $4.0 \mathrm{de}$ & -23.8 & n.e. ${ }^{y}$ & -35.0 & 0.7 & $0.6 \mathrm{c}$ \\
\hline G.3902 & $3.1 \mathrm{e}$ & -24.2 & $6.2 \mathrm{a}-\mathrm{d}$ & -29.6 & - & $0.9 \mathrm{abc}$ \\
\hline G.4011 & $3.4 \mathrm{e}$ & -20.3 & $3.8 \mathrm{~d}$ & -30.3 & - & $0.7 \mathrm{bc}$ \\
\hline G.4013 & $5.8 \mathrm{bc}$ & -17.8 & $5.6 \mathrm{bcd}$ & -24.4 & 0.0 & $1.7 \mathrm{a}^{*}$ \\
\hline G.4292 & $6.6 \mathrm{bc}$ & -15.1 & $8.2 \mathrm{a}$ & -20.0 & 0.2 & $1.3 \mathrm{~b}^{*}$ \\
\hline G.5087 & $4.1 \mathrm{de}$ & -21.6 & n.e. & $<-35.0$ & 0.3 & $0.9 \mathrm{bc}$ \\
\hline G.5257 & $4.4 \mathrm{de}$ & -27.0 & $8.2 \mathrm{ab}$ & -31.2 & 0.7 & $1.5 \mathrm{ab}^{*}$ \\
\hline V.5 & $8.0 \mathrm{a}$ & -20.2 & $6.6 b^{*}$ & -19.8 & 1.0 & $1.7 \mathrm{ab}^{*}$ \\
\hline V.6 & $7.6 \mathrm{a}$ & -17.7 & $6.5 \mathrm{a}-\mathrm{d}$ & -25.0 & - & $1.4 \mathrm{ab}$ \\
\hline V.7 & $8.2 \mathrm{a}$ & -21.0 & $6.8 \mathrm{ab}^{*}$ & -25.3 & 1.0 & $1.6 \mathrm{ab}$ \\
\hline
\end{tabular}

Bmax is the upper asymptote and TI is the temperature at the steepest slope of the logistic function $\mathrm{y}=\mathrm{Bmax} /\left[1+\mathrm{e}^{\mathrm{b}(\mathrm{TI}-\mathrm{x})}\right]$, where $\mathrm{y}=$ amount of oxidative browning and $\mathrm{x}=$ temperature. Asterisks indicate a significant change in Bmax from October to November and from March to April within a genotype.

${ }^{\mathrm{z}}$ Means separation within a column is by $95 \%$ confidence interval. Means not followed by a letter indicate no significant differences within a column.

${ }^{y_{n}}$.e. is not estimable. Upper asymptote, Bmax, could not be estimated. ${ }^{\mathrm{x}}$ Genotype not measured.

selections. In other genotypes, 'G.41', G.4011, and G.5087, little or no change occurred from October to November, indicating that a considerable degree of cambial acclimation had already occurred by October. Moreover, an additional increase in hardiness that occurred after November was still evident in March and April. Few studies have determined the level of cambial damage that can be sustained with no impact on tree growth. In peach, slight browning to cambial tissue leads to mortality in one cultivar, but more severe browning is needed to induce mortality in another cultivar (Deyton et al., 1996). Considering the importance of the cambium to survival and growth of fruit trees, additional studies are needed to clearly define low temperature injury in this tissue, and its associated impacts.

Year-to-year variation occurred in fall hardiness over the two experiments, underscoring the importance of multiple years of testing to fully characterize hardiness. Over half of the genotypes had greater xylem hardiness in Oct. 2013 than in Oct. 2014, based on a lower TI in 'M.9' and Geneva rootstocks and a lower Bmax in Vineland rootstocks. Temperature in the preceding 3 to $7 \mathrm{~d}$ is correlated with the level of shoot hardiness in apple (Coleman and Estabrooks, 1988; Hong and Sucoff, 1982; Ketchie and Beeman, 1973). The specific temperature pattern that led to the year-to-year variation was not clear, but the minimum temperatures $1 \mathrm{~d}$ before the two Oct. 2013 testing dates were 1 and $-2{ }^{\circ} \mathrm{C}$, respectively. This was several degrees colder than the minimum temperature $1 \mathrm{~d}$ before testing in Oct. 2014 , which was $8.5^{\circ} \mathrm{C}$. Conversely, the lower phloem TI in
Table 5. Maximum phloem browning rating (Bmax) and temperature at the inflection point (TI) of the temperature response curves of 2year-old shoots of apple rootstock genotypes in Oct. 2014, Nov. 2014, Mar. 2015, and Apr. 2015.

\begin{tabular}{|c|c|c|c|c|c|c|}
\hline \multirow[b]{2}{*}{ Genotype } & \multicolumn{2}{|c|}{ Oct. 2014} & \multicolumn{2}{|c|}{ Nov. 2014} & \multirow{2}{*}{$\frac{\text { Mar. } 2015}{\mathrm{Bmax}}$} & \multirow{2}{*}{$\frac{\text { Apr. } 2015}{\text { Bmax }}$} \\
\hline & $B \max$ & TI $\left({ }^{\circ} \mathrm{C}\right)$ & Bmax & TI $\left({ }^{\circ} \mathrm{C}\right)$ & & \\
\hline ‘B.9’ & $5.4 \mathrm{bc}$ & $-31.2 \mathrm{ab}$ & $5.3 \mathrm{ab}$ & $-37.6 a b c$ & $-^{x}$ & $2.9 \mathrm{bc}$ \\
\hline ‘M.9’ & $6.3 b^{z}$ & $-30.2 \mathrm{a}$ & $5.0 \mathrm{ab}$ & $-29.6 \mathrm{a}$ & $1.0 \mathrm{a}$ & $2.8 \mathrm{~b}^{*}$ \\
\hline 'G.30' & $9.0 \mathrm{ab}$ & $-31.1 \mathrm{ab}$ & $6.0 \mathrm{ab}$ & $-30.2 \mathrm{a}$ & - & $3.0 \mathrm{bc}$ \\
\hline 'G.41' & $4.6 \mathrm{c}$ & $-31.7 \mathrm{a}$ & n.e. ${ }^{y}$ & n.e. & - & - \\
\hline 'G.214' & $7.3 \mathrm{~b}$ & $-25.3 b$ & $5.5 \mathrm{ab}^{*}$ & $-20.2 \mathrm{c}$ & $0.0 \mathrm{~b}$ & - \\
\hline 'G.814' & $7.2 \mathrm{~b}$ & $-24.7 \mathrm{~b}$ & $5.9 \mathrm{ab}$ & $-29.6 \mathrm{a}$ & $0.0 \mathrm{~b}$ & $2.2 \mathrm{bc}^{*}$ \\
\hline 'G.935' & $7.5 \mathrm{~b}$ & $-24.6 \mathrm{~b}$ & $4.7 \mathrm{ab}^{*}$ & $-24.8 \mathrm{~b}$ & $3.2 \mathrm{a}$ & $2.8 \mathrm{~b}$ \\
\hline G.3902 & $7.0 \mathrm{bc}$ & $-23.1 b$ & $6.0 \mathrm{abc}$ & $-35 a b c$ & - & $3.0 \mathrm{~b}$ \\
\hline G.4011 & $7.3 \mathrm{~b}$ & $-19.8 \mathrm{ab}$ & $5.2 \mathrm{ab}^{*}$ & $-19.8 \mathrm{c}$ & - & $5.4 \mathrm{a}$ \\
\hline G.4013 & $9.4 \mathrm{a}$ & $-20.2 \mathrm{ab}$ & $6.4 \mathrm{a}^{*}$ & $-24.3 \mathrm{~b}$ & $0.0 \mathrm{~b}$ & $5.0 \mathrm{a}^{*}$ \\
\hline G.4292 & $8.3 \mathrm{ab}$ & $-24.7 \mathrm{~b}$ & $4.2 b^{*}$ & $-20.3 \mathrm{c}$ & $0.3 \mathrm{~b}$ & $2.5 b^{*} *$ \\
\hline G.5087 & $5.8 \mathrm{bc}$ & $-21.3 b$ & $4.7 \mathrm{ab}$ & $-25.0 \mathrm{abc}$ & $0.4 \mathrm{ab}$ & $1.6 \mathrm{abc}$ \\
\hline G.5257 & $6.8 \mathrm{~b}$ & $-24.6 \mathrm{~b}$ & $4.6 b^{*}$ & $-25.4 \mathrm{~b}$ & $0.0 \mathrm{~b}$ & $0.0 \mathrm{c}$ \\
\hline V.5 & $7.1 \mathrm{~b}$ & $-24.8 \mathrm{~b}$ & $2.2 \mathrm{c}^{*}$ & $-22.0 \mathrm{abc}$ & $0.0 \mathrm{~b}$ & $1.0 \mathrm{c}^{*}$ \\
\hline V.6 & $8.2 \mathrm{ab}$ & $-30.4 \mathrm{ab}$ & $2.2 \mathrm{c}^{*}$ & $-25.6 a b c$ & - & $3.0 \mathrm{~b}$ \\
\hline V.7 & $4.6 \mathrm{c}$ & $-23.6 \mathrm{ab}$ & $2.4 \mathrm{c}^{*}$ & $-29.8 \mathrm{a}$ & $0.0 \mathrm{~b}$ & $1.5 \mathrm{c}^{*}$ \\
\hline
\end{tabular}

Bmax is the upper asymptote and TI is the temperature at the steepest slope of the logistic function $\mathrm{y}=\mathrm{Bmax} /\left[1+\mathrm{e}^{\mathrm{b}(\mathrm{TI}-\mathrm{x})}\right]$, where $\mathrm{y}=$ amount of oxidative browning and $\mathrm{x}=$ temperature. Asterisks indicate a significant change in Bmax from October to November and from March to April within a genotype.

${ }^{\mathrm{z}}$ Means separation within a column is by $95 \%$ confidence interval.

${ }^{\mathrm{y}}$ n.e. is not estimable. Upper asymptote, Bmax, could not be estimated.

${ }^{\mathrm{x}}$ Genotype not measured.

Table 6. Maximum cambial browning rating (Bmax) and temperature at the inflection point (TI) of the temperature response curves of 2year-old shoots of apple rootstock genotypes in Oct. 2014, Nov. 2014, Mar. 2015, and Apr. 2015.

\begin{tabular}{|c|c|c|c|c|c|c|}
\hline \multirow[b]{2}{*}{ Genotype } & \multicolumn{2}{|c|}{ Oct. 2014} & \multicolumn{2}{|c|}{ Nov. 2014} & \multirow{2}{*}{$\frac{\text { Mar. } 2015}{\text { Bmax }}$} & \multirow{2}{*}{$\frac{\text { Apr. } 2015}{\text { Bmax }}$} \\
\hline & Bmax & TI $\left({ }^{\circ} \mathrm{C}\right)$ & Bmax & $\mathrm{TI}\left({ }^{\circ} \mathrm{C}\right)$ & & \\
\hline 'B.9' & $8.6 \mathrm{bc}$ & -28.3 & $8.6 \mathrm{ab}$ & -29.9 & $-\mathrm{y}$ & $0.6 \mathrm{~d}$ \\
\hline 'M.9' & $6.7 c^{z}$ & -19.5 & $7.5 \mathrm{~b}$ & -25.3 & 0.0 & 0.9 bcd $^{*}$ \\
\hline 'G.30' & $9.5 \mathrm{abc}$ & -24.4 & $9.1 \mathrm{ab}$ & -25.6 & - & $1.8 \mathrm{a}-\mathrm{d}$ \\
\hline 'G.41' & $9.4 \mathrm{abc}$ & -29.9 & $9.8 \mathrm{a}$ & -29.4 & - & - \\
\hline 'G.214' & $10.0 \mathrm{abc}$ & -26.7 & $7.7 \mathrm{~b}$ & -23.9 & 0.0 & - \\
\hline 'G.814' & $7.0 \mathrm{c}$ & -24.9 & $8.0 \mathrm{ab}$ & -25.4 & 0.2 & $1.4 \mathrm{bc}^{*}$ \\
\hline 'G.935' & $7.4 \mathrm{c}$ & -22.0 & $5.6 \mathrm{bc}$ & -25.8 & 1.0 & $1.1 \mathrm{c}$ \\
\hline G.3902 & $5.4 \mathrm{c}$ & -31.7 & $8.6 \mathrm{abc}$ & -30.3 & - & $1.0 \mathrm{~cd}$ \\
\hline G.4011 & $6.2 \mathrm{c}$ & -20.2 & $6.7 \mathrm{~b}$ & -20.9 & - & $1.5 \mathrm{~b}$ \\
\hline G.4013 & $9.6 \mathrm{abc}$ & -19.7 & $8.5 \mathrm{ab}$ & -21.3 & 0.0 & $1.6 \mathrm{abc} *$ \\
\hline G.4292 & $8.9 \mathrm{abc}$ & -20.9 & $7.3 \mathrm{~b}$ & -19.4 & 0.2 & $1.4 \mathrm{bc} *$ \\
\hline G.5087 & $6.9 \mathrm{c}$ & -21.0 & $4.1 \mathrm{c}$ & -24.9 & 1.0 & $1.9 \mathrm{a}$ \\
\hline G.5257 & $8.4 \mathrm{bc}$ & -24.8 & $8.3 \mathrm{ab}$ & -24.6 & 0.0 & $1.7 \mathrm{ab}^{*}$ \\
\hline V.5 & $9.2 \mathrm{~b}$ & -20.7 & $8.5 \mathrm{ab}$ & -30.2 & 0.0 & $1.7 \mathrm{ab}^{*}$ \\
\hline V.6 & $10.0 \mathrm{a}$ & -25.0 & $7.2 \mathrm{abc}^{*}$ & -30.4 & - & $1.6 \mathrm{abc}$ \\
\hline V.7 & $9.1 \mathrm{~b}$ & -22.7 & $8.0 \mathrm{ab}$ & -30.0 & 0.0 & $1.8 \mathrm{a}^{*}$ \\
\hline
\end{tabular}

Bmax is the upper asymptote and TI is the temperature at the steepest slope of the logistic function $y=\operatorname{Bmax} /\left[1+\mathrm{e}^{\mathrm{b}(\mathrm{TI}-\mathrm{x})}\right]$, where $\mathrm{y}=$ the amount of oxidative browning and $\mathrm{x}=$ temperature. Asterisks indicate a significant change in Bmax from October to November and from March to April within a genotype.

${ }^{\mathrm{z}}$ Means separation within a column is by $95 \%$ confidence interval. ${ }^{\mathrm{y}}$ Genotype not measured. 


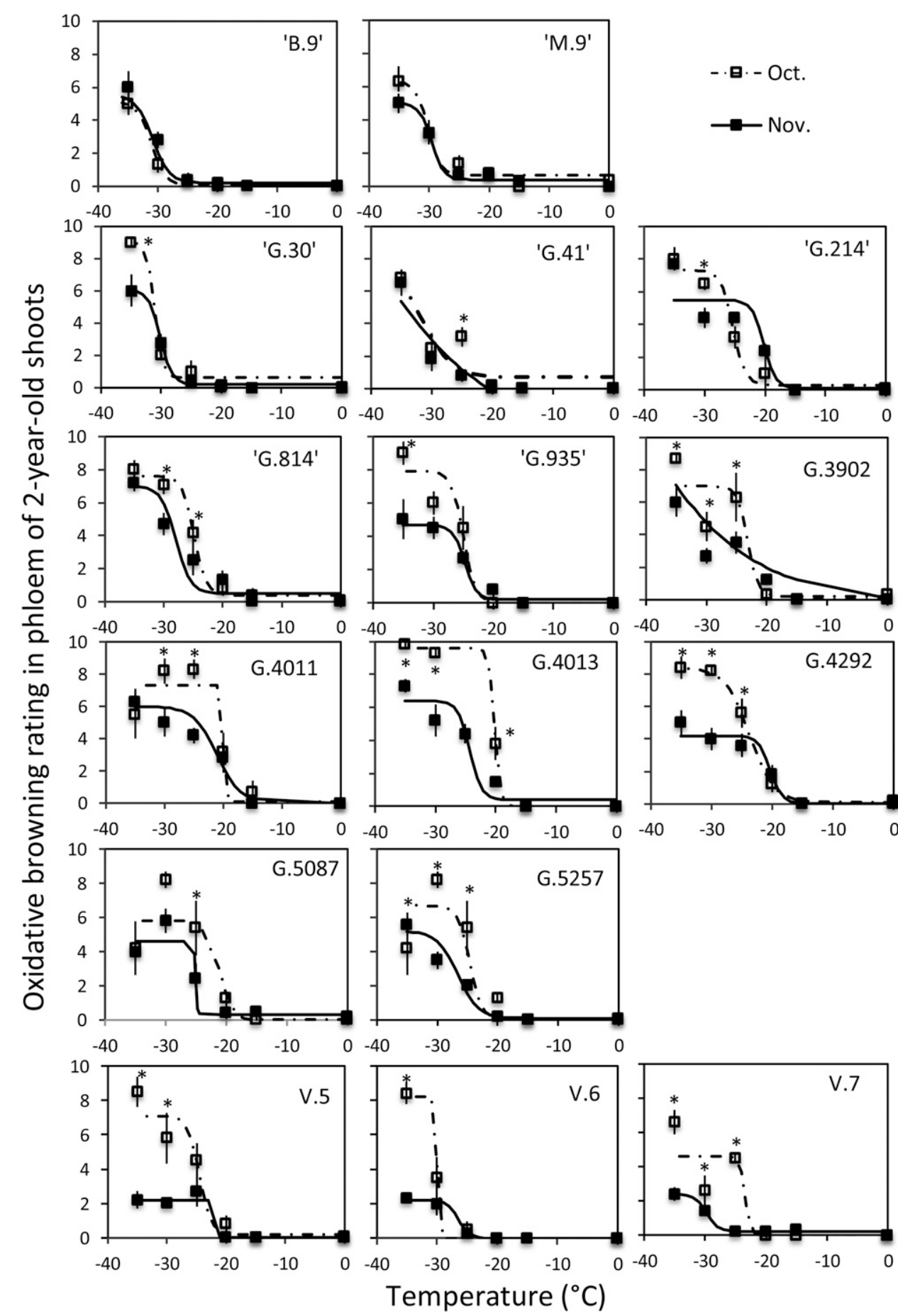

Fig. 8. Phloem browning in 2-year-old shoot pieces in seven apple rootstock cultivars and nine advanced selections exposed to subfreezing temperatures in Oct. and Nov. 2014. Browning was rated as an index whereby index $=$ (proportion of tissue discolored + intensity of discoloration $\times 2$ ) $/ 2$, with proportion of discoloration rated on a scale of 0 indicating none and 10 indicating complete discoloration and degree of darkening using a scale of 0 to 5 , where 0 indicated no browning and 5 indicated dark brown. Asterisks indicate a significant difference in browning between October and November, but within a genotype and temperature.

Oct. 2014 compared with Oct. 2013 indicated greater phloem hardiness in 2014 and an inconsistency in acclimation between xylem and phloem during mid to late October.

Winterhardiness. The high degree of January hardiness in 'G.41', 'G.30', and Vineland selections is consistent with good winter survival compared with 'M.7' and 'M.9' under natural conditions in New York (Robinson et al., 2006) and Ontario. Hardiness of 'M.7' decreased from October to November, whereas Geneva and Vineland genotypes displayed an increase in xylem and phloem hardiness to -35 to $-40{ }^{\circ} \mathrm{C}$, the lower limit of testing in this study. The cambium had achieved winterhardiness to temperatures as cold as -29 to $-40{ }^{\circ} \mathrm{C}$, with 'M.9' and G.3902 resisting injury at $-40{ }^{\circ} \mathrm{C}$. This level of hardiness has been reported previously for xylem in apple shoots (Quamme et al., 1973; Quamme and Hampson, 2004), although mid winter xylem damage has been identified at higher temperatures (Cline et al., 2012). Minimum temperature dropped below $-20{ }^{\circ} \mathrm{C}$ for several days before the Jan. 2014 measurement date, an occurrence that could explain the high degree of shoot hardiness that occurred. Temperatures in the previous weeks affect the level of hardiness (Hong and Sucoff, 1982; Ketchie and Beeman, 1973). In early winter, xylem, phloem, and cambium injury is not likely in fully acclimated apple rootstocks grown in conditions similar to Maine, but other regions with more variable temperatures may experience injury to these tissues (McArtney and Obermiller, 2011).

SPRING HARDINESS. The more frequent and severe winter thaws that could occur with climate change in the eastern United States and Canada could lead to greater low temperature injury (Rochette et al., 2004). Identifying and selecting genotypes with slow deacclimation in response to warming temperatures in late winter could potentially prevent injury and death of trees and limbs. In our study, April shoot hardiness was highly variable between the 2 years. In 2014, a large loss in xylem and cambial hardiness occurred between January and April, with severe browning at -25 to $-35{ }^{\circ} \mathrm{C}$ in every genotype sampled. Measurement of hardiness occurred after several days with maximum temperatures above $10^{\circ} \mathrm{C}$, an occurrence associated with injury to apple trees when followed by severe cold (Caprio and Quamme, 1999). In contrast, xylem and cambium remained very hardy in all genotypes in Apr. 2015, but fewer warm days occurred before measurement. The results in our study indicate that Bmax for cambium and xylem of Geneva and Vineland genotypes 


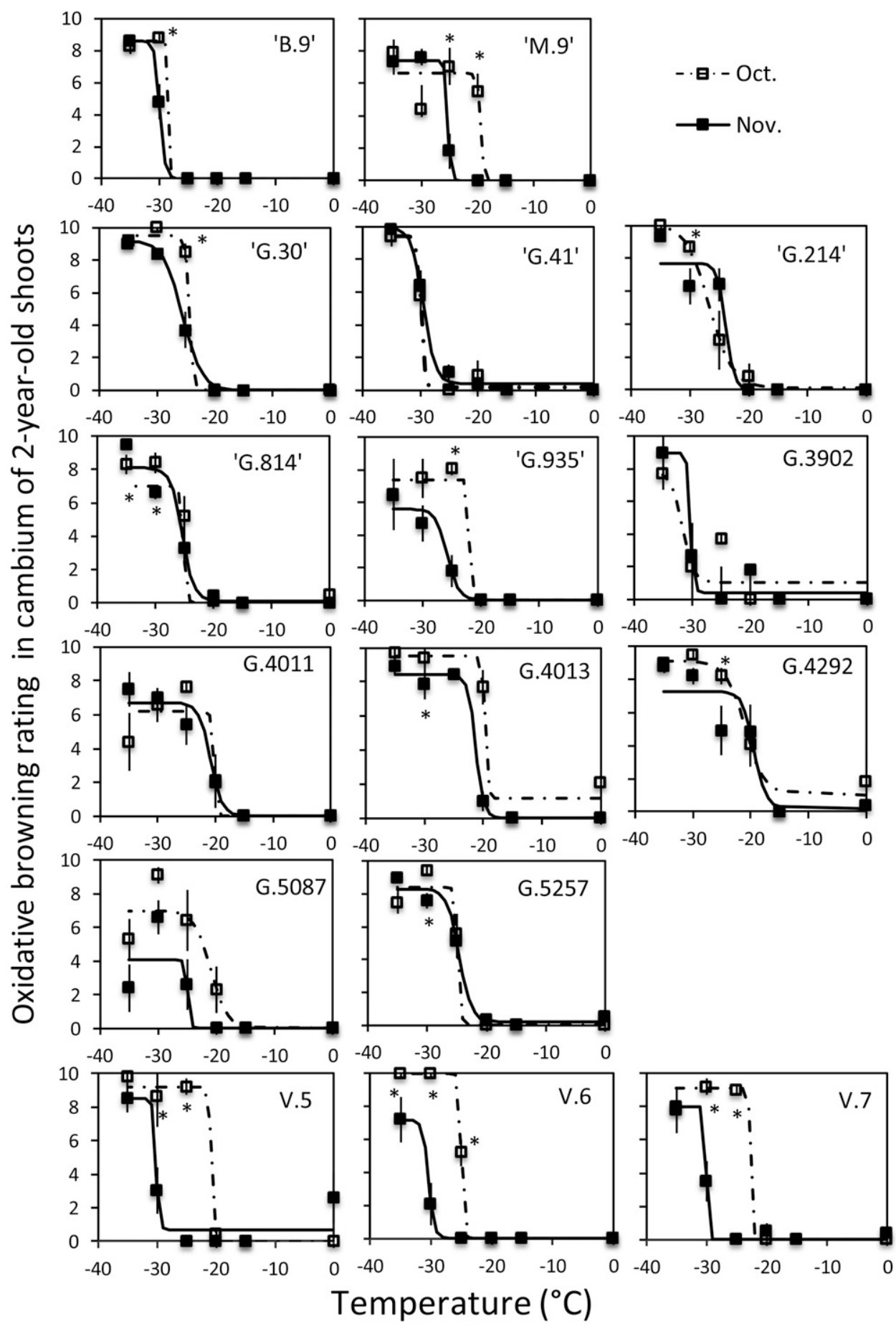

Fig. 9. Cambial browning in 2-year-old shoot pieces in seven apple rootstock cultivars and nine advanced selections exposed to subfreezing temperatures in Oct. and Nov. 2014. Browning was rated as an index whereby index $=($ proportion of tissue discolored + intensity of discoloration $\times 2) / 2$, with proportion of discoloration rated on a scale of 0 indicating none and 10 indicating complete discoloration and degree of darkening using a scale of 0 to 5 , where 0 indicated no browning and 5 indicated dark brown. Asterisks indicate a significant difference in browning between October and November, but within a genotype and temperature.

generally responded similarly to environmental cues that led to earlier deacclimation of the xylem in 2014 and prolonged hardiness in 2015. This is not surprising as all Geneva rootstocks in this study except 'G.30' and 'G.41' were derived from the same cross ('Ottawa 3' $\times$ Malus robusta 'Robusta 5'), and Vineland selections were selected as open-pollinated seeds from one parent, 'Kerr' applecrab $[M$. robusta $\times$ M. domestica (Elfving et al., 1993)]. However, some variation in springtime hardiness occurred among genotypes. Based on the TI in all three shoot tissues, rootstocks 'M.9' and G.3902 appear to be the least vulnerable to injury in April, whereas G.5257 seems most likely to suffer injury following the deacclimation conditions that occurred in this study. Rootstocks 'G.30', 'G.41', 'G.814', and G.4292 could also be vulnerable based on xylem injury at $-20{ }^{\circ} \mathrm{C}$. Injury to the phloem occurred in 'G.41', G.3902, G.4011, G.4013, G.4292, and V.7 in 2014, and in G.4011 and G.4013 in 2015, but at temperatures of $-35{ }^{\circ} \mathrm{C}$ and below. Temperatures this low are rare in April, so phloem injury is unlikely.

Fruit tree rootstocks influence cold hardiness of the scion trunk (Layne, 1994; Layne et al., 1977; McArtney and Obermiller, 2011; Simons, 1970; Westwood and Bjornstad, 1981), but it remains uncertain if the rootstock directly controls the hardiness of the scion. Apple rootstocks can significantly influence the gene expression of scions (Jensen et al., 2012), and while no experiments have been performed to evaluate the influence of scions on rootstock gene expression, it makes sense that there should be some influence. As a combination of scion and rootstock, it is possible that a cold hardy scion may influence the cold acclimation and hardiness of the rootstock, but the same could be true for scions that are not cold hardy. Therefore, the phenotypes described in these experiments could be used to extrapolate whole tree hardiness where it is not possible to test whole tree behavior.

Many promising apple cultivars that possess good shoot hardiness in winter may lack the genetic capacity to adequately develop, or sufficiently retain, cold tolerance during temperature fluctuations in fall and spring (Caprio and Quamme, 1999). Based on the level of hardiness that occurred in this study, it appeared that Geneva and Vineland apple rootstocks have a low degree of susceptibility to injury in January. A high degree of midwinter hardiness is consistent with the selection process in the Geneva series, for which dormant selections were screened for shoot tolerance of $-29^{\circ} \mathrm{C}$ (Cummins and Aldwinkle, 1974), and in the 
Vineland series, for which selection was from a cold tolerant parent (Elfving et al., 1993). Despite this, some genotypes displayed vulnerability in fall and spring. 'G.30' had tender xylem in both the fall and the spring, but hardy phloem in the fall and hardy cambium in the spring. The rootstock G.4013 had the least hardy cambium and phloem in the fall, and G.5257 the least hardy cambium in the spring. These genotypes, along with 'M.7', are likely to be vulnerable to damaging temperatures during fall acclimation or from freeze-thaw cycles in late winter.

\section{Literature Cited}

Caprio, J.M. and H.A. Quamme. 1999. Weather conditions associated with apple production in the Okanagan Valley of British Columbia. Can. J. Plant Sci. 79:129-137.

Cline, J.A., D. Neilsen, G. Neilsen, R. Brownlee, D. Norton, and H. Quamme. 2012. Cold hardiness of new apple cultivars of commercial importance in Canada. J. Amer. Pomol. Soc. 66:174-182.

Coleman, W.K. and E.N. Estabrooks. 1988. An evaluation of the effect of plant growth regulators on cold hardiness in apple trees. Can. J. Plant Sci. 68:859-869.

Cummins, J.N. and H.S. Aldwinkle. 1974. Breeding apple rootstocks. Hort Science 9:13-18.

Deyton, D.E., C.E. Sams, J.C. Cummins, and D.W. Lockwood. 1996. Cambial browning of cold injured peach nursery trees. Fruit Var. J. 50:226-229.

Domoto, P.A., W.R. Autio, G.R. Brown, D.C. Ferree, P.M. Hirst, C.A. Mullins, and J.R. Schupp. 2001. Blackheart injury in 'Golden Delicious', 'Jonagold', 'Empire' and 'Rome Beauty' apple trees on five rootstocks in the 1990 NC-140 cultivar/rootstock trial. J. Amer. Pomol. Soc. 55:146-153.

Einhorn, T.C., J. Turner, D. Gibeaut, and J.D. Postman. 2011. Characterization of cold hardiness in quince: Potential pear rootstock candidates for northern pear production regions. Acta Hort. 909:137143.

Elfving, D.C., I. Schecter, and A. Hutchinson. 1993. The history of the Vineland (V.) apple rootstocks. Fruit Var. J. 47:52-58.

Embree, C. 1988. Apple rootstock cold hardiness evaluation. Compact Fruit Tree 21:99-105.

Holubowicz, T., J.N. Cummins, and P.L. Forsline. 1982. Responses of Malus clones to programmed low-temperature stresses in late winter. J. Amer. Pomol. Soc. 107:492-496.

Hong, S. and E. Sucoff. 1982. Rapid increase in deep supercooling of xylem parenchyma. Plant Physiol. 69:697-700.

Howell, G.S. and C.J. Weiser. 1970a. The environmental control of cold acclimation in apple. Plant Physiol. 45:390-394.

Howell, G.S. and C.J. Weiser. 1970b. Fluctuations in the cold resistance of apple twigs during spring dehardening. J. Amer. Soc. Hort. Sci. 95:190-192.

Jensen, P.J., N. Halbrendt, G. Fazio, I. Makalowska, N. Altman, C. Praul, S.N. Maximova, H.K. Ngugi, R.M. Crassweller, J.W. Travis, and T.W. McNellis. 2012. Rootstock-regulated gene expression patterns associated with fire blight resistance in apple. BMC Genomics 13:9.

Ketchie, D.O. 1985. Cold resistance of apple trees through the year and its relationship to the physiological stages. Acta Hort. 168:131137.

Ketchie, D.O. and C.H. Beeman. 1973. Cold acclimation in 'Red Delicious' apple trees under natural conditions during four winters. J. Amer. Soc. Hort. Sci. 98:257-261.

Lapins, K. 1961. Artificial freezing of 1-year-old shoots of apple varieties. Can. J. Plant Sci. 41:381-393.
Layne, R. 1994. Prunus rootstocks affect long-term orchard performance of 'Redhaven' peach on Brookston clay loam. HortScience 29:167-171.

Layne, R., H.O. Jackson, and F.D. Stroud. 1977. Influence of peach seedling rootstocks on defoliation and cold hardiness of peach cultivars. J. Amer. Soc. Hort. Sci. 102:89-92.

Mathers, H.M. 2004. Supercooling and cold hardiness in sour cherry germplasm: Vegetative tissue. J. Amer. Soc. Hort. Sci. 129:682-689.

Mathers, H.M. and C. Stushnoff. 2005. Screening Malus seedlings for cold hardiness. HortScience 40:318-322.

McArtney, S. and J.D. Obermiller. 2011. Effect of dwarfing rootstocks on low temperature tolerance of 'Golden Delicious' apple trees during winter 2008-2009. J. Amer. Soc. Pomol. Sci. 65:178-184.

Moran, R.E., Y. Sun, F. Geng, D. Zhang, and G. Fazio. 2011. Cold temperature tolerance of trunk and root tissues in one- or two-yearold apple rootstocks. HortScience 46:1460-1464.

Nesmith, W.C. and W.M. Dowler. 1976. Cultural practices affect cold hardiness and peach tree short life. J. Amer. Soc. Hort. Sci. 101:116119.

Palonen, P. and D. Buszard. 1997. Current state of cold hardiness research on fruit crops. Can. J. Plant Sci. 77:399-420.

Pramsohler, M., J. Hacker, and G. Neuner. 2012. Freezing pattern and frost killing temperature of apple (Malus domestica) wood under controlled conditions and in nature. Tree Physiol. 32:819-828.

Quamme, H.A. 1976. Relationship of the low temperature exotherm to apple and pear production in North America. Can. J. Plant Sci. 56:493-500.

Quamme, H., C. Stushnoff, and C.J. Weiser. 1972. The relationship of exotherms to cold injury in apple stem tissues. J. Amer. Soc. Hort. Sci. 97:608-613.

Quamme, H., C.J. Weiser, and C. Stushnoff. 1973. The mechanism of freezing injury in xylem of winter apple twigs. Plant Physiol. 51:273-277.

Quamme, H. and C. Hampson. 2004. Winter hardiness measurements on 15 new apple cultivars. J. Amer. Pomol. Soc. 58:98-107.

Repo, T. and J. Lappi. 1989. Estimation of standard error of impedanceestimated frost resistance. Scand. J. For. Res. 4:67-74.

Robinson, T.L., G. Fazio, H.S. Aldwinckle, S.A. Hoying, and N. Russo. 2006. Field performance of Geneva apple rootstocks in the eastern USA. Scientific Works Lithuanian Inst. Hort. Lithuanian Univ. Agr. 25:181-191.

Rochette, P., G. Belanger, Y. Castonguay, A. Bootsma, and D. Mongrain. 2004. Climate change and winter damage to fruit trees in eastern Canada. Can. J. Plant Sci. 84:1113-1125.

Simons, R.K. 1970. Phloem tissue development in response to freeze injury to trunks of apple trees. J. Amer. Soc. Hort. Sci. 95:182-190.

Steinmetz, F.H. and M.T. Hilborn. 1938. A histological evaluation of low temperature injury to apple trees. Univ. Maine, Maine Agr. Expt. Sta. Res. Bul. 388.

Tanino, K. 2012. From lab to nature: Assessing injury in xylem parenchyma cells. Tree Physiol. 32:815-818.

Warmund, M.R., W.R. Autio, J.A. Barden, J.N. Cummins, P.A. Domoto, C.G. Embree, R.L. Granger, F.D. Morrison, J.R. Schupp, and E. Young. 1996. Blackheart injury in 'Starkspur Supreme Delicious' on 15 rootstocks in the 1984 NC-140 cooperative planting. Fruit Var. J. 50:55-62.

Westwood, M.N. and H.O. Bjornstad. 1981. Winter injury to apple cultivars as affected by growth regulators, weed control method, and rootstocks. J. Amer. Soc. Hort. Sci. 106:430-432.

Wildung, D.K., C.J. Weiser, and H.M. Pellet. 1973. Cold hardiness of Malling clonal apple rootstocks under different conditions of winter soil cover. Can. J. Plant Sci. 53:323-329. 